\title{
Native Hawaiian Land Rights
}

\author{
Neil M. Levy ${ }^{\dagger}$
}

\begin{abstract}
Professor Levy traces the historical displacement of Native Hawaiians from their land and explores the problems of preserving the landholdings and cultural heritage of the Native Hawaiian community. He suggests that the problems require legislative solutions similar to those afforded to Native Americans and Alaskan Natives.
\end{abstract}

In less than 200 years of contact with Western civilization, Native Hawaiians, descendants of Polynesians who inhabited the Islands prior to 1778 , have lost control of the great bulk of their homeland. Today they face a new period of crisis. This arlicle focuses on the historical displacement of Native Hawaiians from their land-a displacement accomphished primarily through legal mechanisms rather than military actions-and then explores the current problems facing the Native Hawaiian community in its attempt to conserve and expand its presently limited landholdings. The article suggests that Native Hawaiians, as an indigenous people, occupy a unique status akin to that of Indians and Alaskan Natives, and that their problems accordingly require special legal solutions.

\section{I}

\section{A History of Native Hawailan Landholdings Until 1920}

\section{A. Traditional Land Tenure}

When Captain Cook arrived in Hawaii in 1778, he found a complex land tenure system, ${ }^{1}$ which has been compared to the feudal sys-

$\dagger$ Associate Professor of Law, Golden Gate University; A.B. 1963, Cornell University; J.D. 1966, University of Chicago.

Preliminary research for this article was begun under a summer grant from the National Endowment for the Humanities. The author wishes to thank Rhoda Haberman, J.D. 1975, Golden Gate University, and Sandra Pechter, J.D. 1974, Golden Gate University, for their invaluable assistance in the preparation of this article.

1. For detailed discussions of early Hawaiian land tenure, see generally J. Chinen, The Great Mahele (1958) [hereinafter cited as The Great Mahele]; G. Daws, Shoal of Time (1968) [hereinafter cited as Shoal of Time]; J. Hobbs, HaWAII-A Pageant of the Soll (1935) [hereinafter cited as Pageant]; 1 R. KuYKendall, The Hawailan Kingdom 1778-1854 (1938) [hereinafter cited as 1 Hawailan KingDom]; A. LIND, AN IsLAND Community (1938) [hereinafter cited as IsLand Community]; M. Kelly, Changes in Land Tenure in Hawaii, 1778-1850, June, 1956 (unpublished thesis in University of Hawaii Library) [hereinafter cited as Kelly]. 
tem of medieval Europe. ${ }^{2}$ This system successfully sustained an extremely dense population ${ }^{3}$ and provided surplus goods sufficient to support chiefs and priests and to replenish Cook's expedition. ${ }^{4} \mathrm{Al}-$ though there were larger admimistrative divisions, ${ }^{5}$ the basic landholding umit was the ahupuaa, which ranged in size from 100 to 100,000 acres and usually had natural boundaries. ${ }^{6}$ The ideal ahupuaa was an economically self-sufficient, ${ }^{7}$ pie-shaped unit which ran from inountain tops down ridges to the sea. Most ahupuaa were in turn divided into ili, some of which were virtually independent while others were mere operating subdivisions of the ahupuaa. A hierarchical society paralleled this pattern of land division. At the top, a chief controlled each ahupuaa; land agents (konohiki) and subchiefs subordinate to the chief controlled smaller amounts of land; and at the bottom of the hierarchy common farmers worked land for the chief's personal benefit. Commoners also had plots for their own use and had certain gathering rights in the noncultivated lands of the ahupuaa. ${ }^{8}$

No concept similar to the fee simple absolute existed at this time and landholdings were considered revocable. On the death of a high chief, his successor was free to redistribute the land among the low chiefs and, when any chiefs died, the lands were not necessarily passed on to the decedent's heirs. Frequent warfare often brought new chiefs who could reassign the conquered land to their followers, rather than leave it with the conquered nobles. These changes in control usually affected neither the boundaries of the ahupuaa and the $i l^{9}$ nor the tenure, such as it was, of common farmers. ${ }^{10}$ Although a commoner in Hawañ owed a work obligation to those higher in the structure, he was free to leave an ahupuaa if unhappy with his landlord. This situation, which distinguished pre-Cook land patterns from the European feudal system, may have been a major factor in ameliorating abuses by the chiefs, who were anxious to keep ample work forces on their lands. ${ }^{11}$

2. See, e.g., Pageant, supra note 1 , at 1 .

3. An estimated three hundred thousand people lived on 6,415 square miles. R. Schmitt, Demographic Statistics of Hawail: 1778-1965, at 10-11 (1968).

4. See 1 Hawalian Kingdom, supra note 1, at 12-20.

5. The island (mokupuni) was the primary division, followed by a geographic division called the mokuaina. Although this was not a political unit, modern Hawaiian judicial districts tend to follow old mokuaina boundaries. The Great MaHeLE, supra note 1 , at 3 .

6. Id. at 1-3; see discussion of boundary setting practices in In re Boundaries of Pulehunui, 4 Hawaii 239 (1879).

7. But see Kelly, supra note 1, at 32 . Occasional trade fairs were held for goods not available in all localities.

8. See id. at 20-26.

9. Id. at 3. Today many large estates follow the boundaries of old ahupuaa and ili kupono.

10. See Pageant, supra note 1 , at 7.

11. See Kelly, supra note 1 , at 42 . 


\section{B. Transitional Period 1778-1846}

The arrival of Westerners completely altered socio-economic patterns as Hawaii became a major refreshment stop for European vessels sailing the Pacific and a major supplier of the sandalwood trade. ${ }^{12}$ Partially through the use of European arms, Kamahameha I had expanded his rule by 1795 to all of Hawaii except the island of Kauai. ${ }^{13}$ A proliferation of administrative levels and a rise in palace court life accompamed this unification. The king and his court were attracted to newly available European and Oriental goods, so that the Hawaiian economy had to supply a now enlarged aristocratic class with imported luxuries. While the economy thus turned from one primarily aimed at subsistence to one enmeshed in international trade, the commoners' condition worsened as Western diseases destroyed much of the population, ${ }^{14}$ traditional notions of feudal responsibility were disrupted, and an onerous tax system was instituted. ${ }^{15}$

Land tenure patterns reflected and served this new economy. Kamehameha II, who acceded to the throne in 1819 , considered it politically unwise to revoke the holdings of his predecessor's subchiefs. Foreign traders were anxious to codify this new stability, fearing that changes in landholdings might lead to civil wars and disruption of commerce. When Kamehameha III acceded to the throne at the age of twelve, the council of chiefs, under the tutelage of an English frigate captain, extracted froin the regent a formal policy, later characterized as the Law of 1825, which allowed chiefs to keep their lands upon a king's death. ${ }^{16}$ At the same time, Westerners entered Hawaii's land usage patterns as foreign settlers were "given" lands by the king or chiefs in return for services or merely out of traditional Hawaiian generosity. ${ }^{17}$ After overharvesting collapsed the sandalwood trade, Westerners witl substantial capital accumulated in that trade began largescale plantations on the Islands. ${ }^{18}$

12. IsLand Community, supra note 1, at 9-11.

13. See 1 Hawailan KIngDom, supra note 1, at 29-60, for description of Kamehameha's conquiest of other kingdoms within the Islands. The independence of Kauai was eroded over the next several decades.

14. IsLAND Community, supra note 1, at 94-99.

15. Id. at 41 .

16. 1 HAWAIIAN KINGDOM, supra note 1, at 119-22.

17. See Keelikolani v. Robinson, 2 Hawaii 514 (1862) for a description of one such land transfer in 1827. See also Pageant, supra note 1, at 17-19.

18. Three Americans started the first venture in 1835 under the name of Ladd $\&$ Co., by obtaining a fifty-year lease, signed by both the king and his governor on Kauai, for a 1000-acre parcel on that island. The lease contained no terms concerning the rights of tenants but provided that Ladd \& Co. might hire native laborers to work the land if it made adequate payments to the laborers, the governor and the king. The transaction thus combined the modern Western lease for a term of years with a partially 
Hawaii's first written constitution, adopted in 1840, and the laws immediately enacted pursuant to it, ${ }^{19}$ attempted to adjust land rights to the new relationships between Hawaiian chiefs and commoners and Hawaiians and Westerners. The constitution and the laws are frequently viewed as liberalizing forces ${ }^{20}$ because they announced tenants' rights in land and lowered labor taxes. They also represent, however, a final attempt to preserve the non-mercantile land systern and to reverse the tide of Hawaiians who were leaving their traditional homes for the booming towns of Honolulu and Lahaina. For example, one statute provided that, "No man living on a farm whose name is recorded by his landlord, shall without cause desert the land of his landlord. Nor shall the landlord causelessly dispossess his tenant."21 Native Hawaiians who had already left the land were offered an opportunity to return by applying to a governor or the king for any uncultivated lands. ${ }^{22}$

The constitution also attempted to deal with two areas of conflict between Hawaiians and Westerners: attempts by chiefs to vest land rights in Westerners without the approval of the crown, and attempts by Westerners, who had received land rights from the king, to transfer those interests to other foreigners without the king's express permission. The traditional Hawaiian land system did not confront these issues, since landholdings before the law of 1825 had been revocable at the pleasure of the king. In disputes over land rights between the king and foreigners, the foreign community had distinct advantages.

feudal labor arrangement. Lease agreement reproduced in part at 1 HAwAIAN KINGDOM, supra note 1 , at 175 .

19. These documents frequently evidence a strong missionary flavor. See, e.g., Law of Nov. 9, 1840, ch. $3, \& 5$, in TRAnslation of the Constrtution and Laws of the Hawailan Islands Established in the ReigN of KamehameHa III (1842) 32 [hereinafter cited as Translation]; (The Fundamental Law of HawaIr 18 (L. Thurston ed. 1904) [hereinafter cited as Thurston]). "As for the idler, let the industrious put him to shame, and sound his name from one end of the country to the other." Thurston at 18.

The statute book cited above is the first compilation in English of the constitution of 1840 and the laws enacted withm the two years following its passage. Hawaii has reproduced its early statutes in other volumes. Since statute books for the Hawaiian Kingdom are now extremely rare, this article will give a parallel citation where applicable to Thurston and to 2 ReVISED LAws of HAwAII 1925 [heremafter cited as REVISED Laws 1925].

20. See, e.g., 1 HawaIran KIngdom, supra note 1 , at 167.

21. Act of Nov. 9, 1840, ch. 3, $\$ 6$, in Translation at 33; (Thurston at 18-19).

This attempt proved futile: "Neither the laws of 1839 nor of 1840 were found adequate to protect the inferior lords and tenants, for although the violators of law, of every rank, were liable to its penalty, yet it was so contrary to ancient usage, to execute the law on the powerful for the protection of the weak, that the latter often suffered, . . " Principles Adopted by the Board of Commissioners to Quiet Land Titles, Act of Oct. 26, 1846, [1846] Hawaii Laws 87 (REvised Laws 1925 at 2127). For further discussion of the Principles see text accompanying note 36 infra.

22. Act of Nov. 9, 1840, ch. 3, \$ 6, in TransLation at 34 (Thurston at 19). 
First, foreign gunboats frequently came to Hawaii to enforce the merchants' views. ${ }^{23}$ Second, Westerners had assumed many of the most important positions and thus were able to influence government decisions. ${ }^{24}$ Native Hawaiians had come to fear the foreigners' accumulation of land. ${ }^{25}$ The chiefs realized that such holdings would increase the power exercised by foreigners and decrease their own ability to receive labor dues from commoners who became part of the Western plantation economy.

In attempting to delimit the Westerners' claims to land, the constitution of 1840 reaffirmed that the king could lose no land without his consent; ${ }^{26}$ thus he could prevent alienation to foreigners. However, fearing a confrontation with Westerners, the king provided in the constitution that property already held by them would not be reclaimed by the crown. ${ }^{27}$ In 1841 , Kamehameha III again sought to forestall conflict with the foreign community by proclaiming a plan of accommodation allowing the Islands' governors to enter into fifty-year leases with the foreigners. ${ }^{28}$ Neither the constitution nor the accommodation plan put to rest Western-Hawaiian land disputes. In 1843, partially in response to a lease dispute involving the British Consul, Richard Charlton, the Britislı warship Carysfort entered Honolulu and its captain took over virtually all functions of government for five months. ${ }^{20}$ The British

23. In 1837, one prominent American merchant wrote:

Property is much safer here than formerly-the visits of the American, English and French men-of-war during these sixteen months have established inviolability of property and persons, and the natives taught and made to fear the

"laws of the Nations"; and that a sovereign and a government come under the ban of laws as well as subjects or individuals.

Letter from Henry A. Pierce to James Hunnewell, Aug. 6, 1837, in 1 Hawalian KingDOM, supra note 1 , at 153 .

24. See Kuykendall, American Interests and American Influence in Hawaii in 1842, 1930 ANn. Report of the Hawaitan Historical Soc'y 61 (1930).

25. See, e.g., petition from natives of Molokai and Maui to the King, July, 1845, objecting to the land being sold to Westerners, Legislative File Folder \#2, Hawaii State Archives.

26. The constitution of 1840 stated:

KAMEHAMEHA I, was the founder of the kingdom, and to him belonged all the land from one end of the Islands to the other, though it was not his own private property. It belonged to the chiefs and people in common, of whom Kamehameha I. was the head, and had the management of the landed property. Wherefore, there was not formerly, and is not now any person who could or can convey away the smallest portion of land without the consent of the one who had, or has the direction of the kingdom.

Constitution of 1840, in Translation at 11-13 (Thurston at 3 ).

27. Preamble to constitution of 1840 , in Translation at 10 (Thurston at 1 ). This preamble had been proclaimed by Kamehameha III in 1839 in virtually the same form as it appeared in the constitution and is frequently referred to as the Declaration of Rights. at 275 .

28. Royal Proclamation, May 31, 1841, in 1 HAwanAN KINGDoM, supra note 1 ,

29. See generally SHOAL OF TIME, supra note 1 , at 112-120. 
government, upon learning of this action, repudiated it and ordered the Carysfort to leave Hawain. To the Hawaiian Kingdom the lesson must have been clear: its independence was at the whim of great Western powers, whose nationals increasingly desired to own the lands of Hawaii.

\section{Era of the Mahele}

By 1845 , the land tenure system could neither maintain itself in the face of a hostile foreign world nor accommodate itself to the wishes of that world. The government's response to these problens was a time honored one: appoint a commission. The Land Commission was charged to undertake "the investigation and final ascertainment or rejection of all claims of private individuals, whether natives or foreigners, to any landed property acquired anterior to the passage of this Act. ....30 Its decisions, subject only to appeal to the Hawaii Suprene Court, were to be based on existing land law of the kingdom, including "native usages in regard to landed tenures." 31 Its ethnic coinposition illuminates the hold which non-Hawaiians had obtained on important government positions: of the Commission's five meinbers, two were Hawainans, one was half-Hawaiian, and two were Westerners. ${ }^{32}$

Under the traditional land system, especially after the constitution of 1840, holdings of the king, chiefs and commoners were intertwined and undivided. Lacking guidelines to undertake the division of those interests, the Commission at first did not act on the bulk of Hawaiian lands. Instead it focused its immediate attention on building lots in Honolulu and Lahaina simce this land had already left the feudal production scheme. ${ }^{33}$ Claimants proving rights in these lands received Land Commission Awards specifically stating that the Commission found "no native rights of occupancy in this plot." cept of fee simple was not part of the Hawaiian land systein at that time, the Minister of Interior was authorized to issue fee patents based upon these awards. ${ }^{35}$ The Commission was thus able to resolve a number of land disputes which had developed with the foreign community.

30. Act of Dec. 10, 1845, ch. 7, $\S 1,2$ [1847] Hawaii Laws 107, in REvised LAws 1925 at 2120 (Thurston at 137).

31. Id. $\$ 7$ at 109, in REVISED LAws 1925 at 2123 (Thurston at 138-39).

32. 1 HAWAIIAN KINGDOM, supra note 1 , at 280.

33. See 2 [1847] Hawaii Laws 84, in Revised Laws 1925 at 2127 (Thurston at 143).

34. For English language copies of early land Commission Awards and Royal Patents, see J. ChInen, Original Land Trtles in Hawain 8-9 (1953).

35. Act of Dec. 10, 1845, ch. 7, \& 9 [1846] Hawaii Laws 109, in Revised Laws 1925 at 2123 (Thurston at 139). But see 1 HAWAIIAN KINGDOM, supra note 1, at 28284 for discussion of the limited government experiment in 1845 of selling small lots with fee simple title in the Makawao district of Maui and the Manoa valley on Oahu. 
In 1846, the Commission adopted Principles, ${ }^{36}$ ratified by the legislature, ${ }^{37}$ to guide its work with land still under the traditional system. The Westerner-dominated Commission perceived its goal to be a total defeudalization and partition of undivided interests. ${ }^{38}$ In discussing a fair and equitable division between king, chiefs, and tenants, the Principles stated:

If the King be disposed voluntarily to yield to the tenant a portion of what practice has given to himself, he most assuredly has a right to do it; and should the King allow to the landlord one-third, to the tenant one-third and retain one-third himself, he, according to the uniform opinion of the witnesses, would imjure no one unless himself; ... According to this principle, a tract of land now in the hands of landlord and occupied by tenants, if all parts of it were equally valuable, might be divided into three equal parts . . . . ${ }^{39}$

The specifics for fulfilling the Principles were much debated until a formulation drafted by a Westerner, Justice William Lee, was accepted by the king and chiefs in Privy Council on December 18, 1847. The Lee formulation distinguished the king's private lands (those he held directly as noble) from lands he held as king and provided that he should retain all his private lands, with a right in his tenants "to a fee simple title to one-third of the lands possessed and cultivated by them" whenever the king or tenants desired. ${ }^{40}$ The remaining land of the kingdoin was to be divided into thirds: one-third to the Hawan̈an government, another third to the chiefs and land agents, and the final third to the tenant farmers. ${ }^{41}$ By paying the government, a chief or konohiki could also retain his proportional share of the one-third that was to go to the government. ${ }^{42}$

36. Principles Adopted by the Board of Commissioners to Quiet Land Titles in their Adjudication of Claims Presented to Them, Act of Oct. 26, 1846, 2 [1847] Hawaii Laws 81, in Revised LAws 1925 at 2124 (Thurston at 140).

37. The ratification declared that "all claims for landed property in this kingdom shall be tested by those principles and according to them be confirmed or rejected." Resolution of the Legislative Council, 2 [1847] Hawaii Laws 94, in Revised Laws 1925 at 2137 (Thurston at 154).

38. Act of Oct. 26, 1846, 2 [1847] Hawaii Laws 81, 92, in Revised Laws 1925 at 2134 (Thurston at 151).

39. Id. at 83, in REVISED LAws 1925 at 2126 (Thurston at 142-43).

40. Rules adopted by the Privy Council, Dec. 18, 1847, \& 4, 4 Prvy CounciL RECORD (1847), quoted in Alexander, A Brief History of Land Titles in the Hawaiian Kingdom, in Thrum's Hawaitan Almanac and ANNual for 1891 at 112.

41. $I d$. at $\& 2$.

42. Id. $\$ 6$ at $112-13$. The commutation was often reduced or virtually eliminated by Privy Council action. Cf. 1 HAwaIIAN Kingdom, supra note 1 , at 288 . Moreover, many konoliki sinply failed to make the payment. In 1892, after much of the land had passed into non-Hawaiian hands, a statute was passed setting the commutation as one-third the value of the land at the time of the Mahele, without interest. Act of Dec. 16, 1892, ch. 68, \& 1 [1892] Hawaii Laws 165, in REVISED LAWs 1925 at 2151. 
The "Great Mahele"-or division-began January 27, 1848, and ended March 7. In the "Mahele Book," the interests of 245 chiefs and konohiki were divided from the king's private interest and the king quit-claimed his interest in specific ahupuaa and ili under each chief's control. The chiefs reciprocally quit-claimed to the king their interests in the balance of the divided lands, which then became the king's private land subject only to commoners' claims to one-third of that which they possessed and cultivated. Nevertheless, on March 8, 1848, the day after the last mahele between king and chiefs, the king "set apart forever to the chiefs and people of my Kingdom" approximately 1,500, 000 acres, $^{43}$ retaining for himself, his heirs and successors approximately $1,000,000$ acres. The latter were subsequently referred to as Crown lands and the former as Government lands. The Land Commission then awarded the remaining 1,500,000 acres of the kingdom to the chiefs ${ }^{44}$ though these awards stated specifically that they were "reserving the rights of the people." 45

Total defeudalization of landholdings required the Commission to divide and parcel out the interests of the common people. An 1850 act $^{46}$ allowed each tenant to apply for his own kuleana. The kuleana could come from the Crown lands, from the Government lands created by the king, or from the other 1,500,000 acres of the kingdom, and could only include land which a tenant had "really cultivated"47 plus a houselot of not more than a quarter of an acre. ${ }^{48}$ The tenant received a fee title to this land if the claim was proved before the Land Commission and survey costs were paid. ${ }^{49}$ The Commission, the legislature, and the king had previously promised the commoners an un-

Even then, a statute had to be adopted in 1909 to provide for enforcement of the payments. Act of April 20, 1909, Act 90, \$ 1, [1909] Hawaii Laws 118.

43. The division was affirmed by legislation. Act of June 7, 1848, [1848] Hawaii Laws 22, in ReVsed Laws 1925 at 2152. at 127.

44. See IsLand Community, supra note 1, at 46; SHoAl of Time, supra note 1 ,

45. An English language copy of such a patent can be found in J. CHINEN, ORIGINAL LAND Trtzes IN HAWAII 9 (1953). Because of this reservation, a kuleana award made later in time was good against an earlier patent. See Kekiekie v. Dennis, 1 Hawaii 69 (1851).

46. Act of Aug. 6, 1850, $\$ 1$ [1850] Hawaii Laws 202, in 2 Revised LAws 1925 at 2141. Actually, a joint resolution of the Legislature of Nov. 7, 1846 had similarly allowed the Minister of the Interior to divide out the interests of tenants. $\$ \$ 4-5$ 2 [1847] Hawan Laws 71. However, hittle came of that power, probably because of insufficient government mechanisins to deal with it.

47. Act of Dec. 21, 1849, $\$ 6$, [1850] Hawaii Laws 203, in Revised Laws 1925 at 2142 .

48. Id. § 5, in Revised LAWs 1925 at 2142.

49. Except for houselots in Honolulu, Lahama and Hilo, kuleana recipients did not have to pay any commutation in order to receive their titles. Id. $\S 2$, in REVISED LAws 1925 at 2141-42. 
divided one-third interest in most of Hawaii. ${ }^{50}$ Although many historians have viewed the Kuleana Act as a beneficent one, ${ }^{61}$ creating more than 8,000 yeoinan holdings, ${ }^{52}$ commoners received divided title to fewer than 30,000 acres, less than one percent of the land. ${ }^{\text {b3 }}$

Many reasons have been advanced for the scant quantity of land that commoners received. One suggestion is that most commoners lacked even the sinall capital needed for the required survey. Another is that commoners did not apply for kuleana because they feared reprisals by chiefs and land agents. ${ }^{54}$ While these suggestions explain the number of commoner families receiving grants, the inore cogent reason why commoners received so little kuleana land is that kuleana grants were severely limited by the "really cultivated" clause of the Kuleana Act. Furthermore, an act of the legislature barred all coinmoners' land claims not proved by 1854.55 Thus, the great bulk of Hawaiian people was separated froin the lands of Hawaii. Transferable title to almost two-thirds of Hawaii was concentrated in the hands of the king and the 245 recipients of mahele grants. The failure of the kuleana to provide an adequate land base for Native Hawaiians was not inerely a function of kuleana size. Historically, commoners had only small fields to work for their own benefit, but they also were able to use other non-cultivated lands within the ahupuaa in return for labor dues. In 1847 , the legislature had specifically confirmed the

50. See text accompanying notes 39-41 supra.

51. See, e.g., Lydgate, The Vanishing Kuleana, Thrum's Hawnitan Almanac AND ANNUAL FOR 1915 at 103.

52. Recent research by Marion Kelly, historian, Bishop Museum, Honolulu, Hawaii determined the number of recipients to be 8205 . Letter from Marion Kelley to Neil Levy, February $18,1975$.

53. 1 HAWAIIAN KINGDOM, supra note 1, at 294. Compare the effect of the General Allotment Act, ch. 119, 24 Stat. 388 (1887) on mainland Indian tribes. Under the guise of turning Indians into yeomen farmers, that act gave interests in tribal property to individual Indians and distributed the "excess" to non-Indians. See D. OTIs, THe DAWES ACT AND THE ALLOTMENT OF INDIAN LANDS (1973).

54. See, e.g., Morgan, Hawail-A Century of Economic Change 1778-1876, at 137 (1948).

55. An Act Relating to the Board of Commissioners to Quiet Land Titles, [1853] Hawaii Laws 26, in REvisEd LAws 1925 at 2145. Under Hawaiian case law, decisions of the Land Commission could not later be collaterally attacked. Kaai v. Mahuka, 5 Hawaii 354 (1885); Kukiiahu v. Gill, 1 Hawaii 90 (1851).

In the 1850's one might have argued that the Kuleana Act merely divided out a small portion of the commoners' interests under the Lee formulation and that the commoners should have been entitled to the remainder of those interests. If such a governmental taking argument was made before the Land Commission or the Supreme Court of Hawaii, it did not succeed. It must be recalled that the Hawaiian Constitution of 1840 had no clause requiring compensation for the taking of property. The closest provision to a due process clause was the preamble which stated that "nothing whatever shall be taken from any individual except by express provision of law." TransLation at 10 (Thurston at 1 ). 
common people's right to grow crops for their own use and to pasture animals on unoccupied lands. ${ }^{56}$ The Kuleana Act withdrew the right to grow crops and pasture and merely provided some gathering rights, ${ }^{57}$ which meant little to a weak tenant surrounded by large fenced landholdings. Thus the foreigners heightened the hierarchical structure of Hawaïan society by renoving its ameliorative qualities.

The transformation to the modern Hawaiian land system was completed by creating formalized mechamisms for the sale of government lands and by allowing aliens to own land in Hawaii. Acts in $1846^{58}$ authorized government land sales approved by the king and Privy Council and, by May 1,1850, the government had sold over 27,000 acres under these laws. ${ }^{59}$ Subsequently, the Kuleana Act directed that portions of government land be set aside in lots of one to fifty acres for purchase by natives who did not qualify for kulean $a^{60}$ and fixed a minimum price of 50 cents per acre. ${ }^{61}$ Although these laws allowed common people who had not received kuleana the chance to own land, they did so at the price of establishing the primciple that government land could be sold off. By 1852, thousands of acres of prime Hawaiian land were in the hands of foreigners. More importantly, Western property concepts were imposed on the legal structure and would facilitate the rapid, steady takeover of Hawaiian-owned lands during the next several decades. Moreover, the government's commitment to selling its remaining land put Westerners, with their access to capital, in a position to take Hawairan land through the legal procedures they had established. ${ }^{.2}$ Western Imperialism had been accomplished without the usual bothersome wars and costly colonial administration.

Apologists for missionaries and other early Westerners might argue that the introduction of nineteenth-century Western property no-

56. Resolution of November 7, 1846, $\S \S 1-2,2$ [1847] Hawaii Laws 70.

57. Act of August 6, 1850, $\$ 7$, [1850] Hawaii Laws 203, in Revised Laws 1925 at 2142. Oni v. Meek, 2 Hawaii 87 (1858) interpreted the Kuleana Act as implicitly repealing all former gathering rights.

58. Law of April 27, 1846, ch. 7, \$§ 1-3, [1846] Hawaii Laws 99-103, in REvised LAws 1925 at 2190; Resolution of Nov. 7, 1846, § 6, 2 [1847] Hawaii Laws 71.

59. PageANT, supra note 1 , at 54 .

60. Act of August 6, 1850, § 4, [1850] Hawaii Laws 203, in Revised Laws 1925 at 2142.

61. Act of July 11, 1851, [1851] Hawaii Laws 52-53.

62. An 1847 amendment of the Land Commission law permitted foreigners to receive title to lands in which they had had an interest before 1845. Act of June 28, 1847, 2 [1847] Hawaii Laws 78, in REvised Laws 1925 at 2233. A limitation in that amendnent, which provided that Western-held land could only be resold to Native Hawaiians, was negated by legislation in 1850: Act of July 10, 1850, [1850] Hawaii Laws 146-147, in ReVISED LAws 1925 at 2233-34. The 1850 legislation allowed any resident of Hawaii to own land regardless of citizenship. The sole disability against foreign property owners, concerning escheatment, was removed in 1854. Act of June 28, 1854, [1854] Hawaii Laws 15, in Revised LAws 1925 at 2235. 
tions helped break a pernicious feudal system, or that the Western community in Hawaii could not have foreseen the harsh effects of defeudalization and the difficulties which a people face in turning from a feudal to a capitalist economy. A more realistic observer can conclude, however, that the foreigners were motivated by greed. Rev. Richard Armstrong wrote to his brother on January 15, 1850:

The government has lately granted fee simple titles to all the natives, for the land they have lived on and occupied. This gives the final blow to the old feudal system and makes this a nation of freeholders. It is a point for which $I$ lave long contended and finally on my own motion it was carried by the King and Council. On their part it lost a great struggle as it cuts them off, at once, from the labour of all their tenants, and they must now work their lands by hired labour. This will compel them to sell their waste lands of which they have an abundance. ${ }^{.3}$

\section{The Plantation Economy}

With a pernuanent population of fewer than two thousand, Westerners took over most of Hawaii's land in the next half-century ${ }^{64}$ and manipulated the economy for their own profit. ${ }^{65}$ They had already stripped the land of its only readily exploitable resource, sandalwood.00 After the Reciprocity Treaty of $1876,{ }^{67}$ which allowed Hawaiian sugar to enter the Umited States duty-free, Western-owned sugar plantations dominated the Hawaiian economy. ${ }^{68}$ That the local population did not participate in this economy proved no obstacle; laborers were imported froin the Orient and Europe. ${ }^{69}$ By the turn of the century Hawaiians were a minority in their own homeland. ${ }^{70}$

63. Letter on file in Library of Congress, Armstrong-Chapman papers; copy on file, Hawaiian Mission Children's Society, Honolulu, Hawaii (emphasis added).

64. In 1897 , the Western 9 percent of the population, owned 67 percent of the taxable lands, while Hawaiians and part-Hawaiians owned only 24 percent. IsLAND COMMUNITY, supra note 1 , at 57.

65. For detailed histories of Hawaii during this period see generally $\mathrm{R}$. Horowitz, L. Vargha, J. Finn, \& J. Ceaser, Public land Policy in Hawain: AN HisTORICAL ANALYSIS (Legislative Reference Bureau Report No. 5, 1965) [hereinafter cited as Historical Analysis]; 2 R. KuYkendall, The Hawailan Kingdom 1854-74 (1953) [hereinafter cited as 2 HawaIIAN Kingdom]; 3 R. KuYkendall, The Hawailan KINGDOM 1874-93 (1967) [hereinafter cited as 3 HawaInaN KINGDOM]; J. Morgan, HawaII: A Century of Economic Change (1948) [hereinafter cited as Censtury op ECONOMIC CHANGE].

66. Century of Economic Change, supra note 65, at 61-68.

67. Treaty with Hawaiian Islands, January 30, 1875, [1875] 19 Stat. 625, T.S. No. 161; Act of July 18, 1876, ch. 2, [1876] Hawaii Laws 4-6.

68. By $1898,125,000$ acres were in cane sugar. See 3 Hawalun Kingdom, supra note 65 , at 62 . This acreage was the best on the Islands and its economic importance was greater than its proportion of land.

69. Century of EConomic Change, supra note 65 , at 188-194.

70. In 1896, Hawaiians and part-Hawaiians constituted about 35 percent of the population. A. LIND, HaWAII's PEople 27 (1967). 
Plantations were made possible by legislation enabling Westerners to purchase large tracts of government land, ${ }^{71}$ pursuant to which the kingdom sold over 600,000 acres by 1893 at an average price of 92 cents per acre. ${ }^{72}$ Although Native Hawaïans made the largest number of purchases, the bulk of the acreage went to Westerners. For example, before 1864, more than 320,000 acres were sold to only 213 Westerners. ${ }^{73}$ In the following year the entire island of Niihau, over 61,000 acres, was sold to one Western entrepreneur. ${ }^{74}$ Westerners also accumulated Crown lands via leasehold arrangements despite the fact that the Crown lands had been made inalienable in $1865 . .^{75}$ By 1890 , 76 lessees controlled 752,431 acres of Crown and government land by leasing at an annual rate of pennies per acre. ${ }^{76}$

Some Westerners acquired large amounts of acreage for plantations by overreaching or actual fraud. In 1880, Claus Spreckels, the California sugar baron, purchased from a descendant of Kamehameha I all her rights in the Crown lands. ${ }^{77}$ Although this clain had no legal value simce Crown lands were malienable, Spreckels persuaded the 1884 legislature to give him 24,000 acres of high quality sugar land in exchange for his asserted claim. ${ }^{78}$

71. Statutes cited notes 58 and 62 supra. Until the Act of September 25, 1876, [1876] Hawaii Laws 118-119, such sale did not have to be at auction.

72. See Historical ANALYSIS, supra note 65, at 186.

73. Compare the purchase during the same period of approximately 90,000 acres by 333 Native Hawan̈ans. Statistics compiled by the author from Commissioner of PUBLIC LANDS OF THE TERrTtoRY OF HAWAI, INDICES OF AWARDS (1929), containing entries of grantees and acreage for all Royal Hawaiian government land grants.

74. COMmissioner of PUblic LANDS OF THE TERRTTORY OF HAWAI, INDICES OF Awards 10 (1929).

75. Upon the death of Kamehameha IV in 1865, Queen Emma applied under the intestate succession laws for a one-half interest in the estate and a right of dower in the remaining half. Ruling against her, the Hawaiian Supreme Court declared that despite the clear intent of Kamehameha III during the Mahele to have the Crown lands treated as private property, they belonged to the possessor of the Crown, subject only to a dower right. In re Kamehameha IV, 2 Hawaii 715 (1864). This litigation led to legislation which affirmed the decision of the court and further declared that all land remaining with the Crown "shall be henceforth inalienable, and shall descend to the heirs and successors of the Hawaiian Crown forever." Act of January $3,1865, \S 3$ [1864] Hawaii Laws 70, in Revised Laws 1925 at 2178. This act also substituted an incoine of $\$ 6,000$ for the Queen's dower and provided for bonds to redeem existing mortgages.

76. Historical ANalysis, supra note 65, at 137.

77. SHOAL OF TIME, supra note 1 , at 225.

78. Act of July 21, 1882, ch. 10, [1882] Hawaii Laws, in Revised Laws 1925 at 2179 .

Under a statute that authorized government land exchanges, Act of August 14, $1895, \S 17,[1895]$ Hawaii Laws 56-57, Charles Gay exchanged slightly fewer than 300 acres on Oahu for 48,000 acres on Lanai. R. Horowitz, PUBLIC LAND Policy IN HawaII: LAND Exchanges (Legislative Reference Bureau Report No. 2, 1964) 14-15. McCandless v. Carter, 18 Hawaii 221 (1907) upheld this questionable transaction. 
In 1865, Joseph $\mathrm{H}$. Morrison measured the dimensions of an ahupuaa of almost 50,000 acres, reported to the Hawaiian owner that the ahupuaa was only 1,200 acres, and then purchased it for a mere $\$ 600$. The court set aside the transaction, relying not only upon the disparity between the sales price and the true value, but also on the relationship of trust between the buyer and seller. ${ }^{70}$ In other cases, however, courts upheld transactions where the evidence strongly suggested an illiterate seller sold property for far less than its true value, or was confused about the nature of the transaction. ${ }^{80}$

Intermarriage between Western inen and the daughters of landrich Hawaiians also resulted in the loss of Native Hawanan control over land. ${ }^{81}$ The courts facilitated this loss of land. For example, one decision voided an attempt by a Hawaiian woman to transfer land to her brother and thus out of the control of her Western husband. ${ }^{82}$ The administration of the Bishop Estate illustrates another instauce in which Native Hawaiians lost control of the land. ${ }^{83}$ When Bernice Pauahi Bishop, the last descendaut of Kamehameha I, died in 1884, her estate imcluded more than 375,000 acres. $^{84}$ The bulk of her estate was bequeathed to a charitable trust, administered by five named Westerners, whose successors were to be appointed by a majority of the justices of the supreme court. ${ }^{85}$ Thus, even if the charitable estate had been efficiently managed for the benefit of Native Hawaiians, as the testator intended, control of almost 10 percent of the land of Hawaii passed out of Hawaiian hands as a result of the disposition. As Rev. Armstrong had predicted, ${ }^{88}$ the chiefs who had been accustomed to the feudal labor dues systein were unable to manage cash plautations and many large estates were lost through debts and mortgage foreclosures. ${ }^{87}$

79. Kapaakea v. Morrison, 2 Hawaii 272 (1860); see also Ainini v. Kala, 6 Hawaii 16 (1869); Kapea v. Moehonua, 6 Hawaii 49 (1871).

80. See, e.g., Kanakauui v. Leslie, 7 Hawaii 223 (1888); Namomi v. Ah Nui, 5 Hawaii 441 (1885); Kapaukea v. Lawrence, 4 Hawaii 674 (1873).

81. Although the descendants are obviously part-Hawaiiall, subsequent marriages to Westerners have led to a present landholding class whose cultural identity differs from the bulk of landless Hawaiians.

82. Mutch v. Holau, 5 Hawaii 316 (1885).

83. For discussion of present problems of the Bishop Estate, see text accompanying notes 171-217 infra.

84. This accumulation of land in the estate of one person occurred because of the scarcity of heirs in the Kamehameha line. See Midkiff, The Kamehameha Schools and the Bishop Estate, in The KAMEHAMEHa Schools-75TH ANNIVERSARY Lectures 16364 (1965).

85. Will of Bernice Pauahi Bishop, đ 14, Equity file No. 2048 (Hawaii Cir. Ct., 1st Cir., December 2, 1884). Cited in relevant part in Kekoa v. Supreme Court, 55 Hawaii 174, 516 P.2d 1239, 1241 (1973).

86. See text accoinpanying note 63 supra.

87. For account of an early mortgage granted by Native Hawaiians, see, e.g., May v. Haalelea, 2 Hawaii 191 (1859). 
As Westerners gained control over government lands and holdings of the Native Hawaiian aristocracy, the kuleana became easier to obtain and the majority of these minimal holdings were soon lost. ${ }^{88}$ The kuleana owners were frequently harassed by the illegal diversion of water and by foraging cattle from large ranches. ${ }^{89}$ Without the former concomitant rights to grow crops and pasture animals on unoccupied land in the rest of the ahupuaa, ${ }^{90}$ the kuleana could not provide their owners with a subsistence hiving. The economic difficulties in 1naintaining them, plus the absence of restraints on alienation, frequently led to sales at nominal prices. ${ }^{91}$ Kuleana which had been leased to Westerners were never returned ${ }^{92}$ because natural landmarks disappeared when the kuleana became part of plantations. ${ }^{93}$ Kuleana were lost to larger surrounding landholders by frequent invocation of the doctrine of adverse possession..$^{94}$

\section{E. The Republic and the Annexation}

Westerners, having asserted economic dominance over the Islands by the 1880 's, turned to the establishment of complete political control. ${ }^{95}$ Influential Western growers formed the Hawañan League in 1887, whose stated goals were to end corruption in the Hawaiian government and to reduce the 1nonarcli's power. ${ }^{96}$ The group staged a coup d'etat on July 6,1887 , forcing the king to promulgate a new constitution to replace the constitution of 1864 . The "Bayonet Constitution" substituted the power of Western landowners for that of the king. ${ }^{97}$ The upper class of legislators, previously appointed by the king from the Native Hawaiian nobility, ${ }^{98}$ was now to be elected by those

88. For discussion of the current problems of remaining kuleana, see text accompanying notes 145-70 infra.

89. See discussion of the history of cattle on the Islands in Davis v. Green, $2 \mathrm{Ha}$ waii 367 (1861). See also Century of ECONOMic Change, supra note 65, at 169.

90. See text accompanying notes 56-57 supra.

91. Cf. IsLand CoMmunity, supra note 1 , at 47-52.

92. Id.

93. See Wise, History of Land Ownership in Hawaii, in ANCIENT HawaInan CrvILIZATION 89-90 (1956).

94. See text accompanying notes 160-70 infra.

95. See generally S. Stevens, AMERICAN EXPANSION IN HaWAII, 1842-1898 (1945) [hereinafter cited as American Expansion]; M. Tate, The United States and the HaWAIIAN KINGDOM (1965) [hereinafter cited as U.S. AND THE HaWAIIAN KINGDOM].

96. See 3 HAWAIIAN KINGDOM, supra note 65 , at 347-49.

97. For example, the absolute veto power of the monarch under the constitution of 1864 , art. 31 , was reduced to a limited veto power in the constitution of 1887 , art. 48 , in Thurston at 173, 187.

98. Constitution of 1864 , art. 45 , in Thurston at 174 . 
who paid taxes, ${ }^{99}$ from a field of candidates limited to wealthy landowners. $^{100}$ Americans and Europeans residing in Hawaii, who were literate in any Western language and met the taxpaying criteria, did not have to be citizens to vote, ${ }^{101}$ while illiterate Hawainans under the age of 47 were barred from voting. ${ }^{102}$

The political victory of 1887 did not satisfy the desires of those Americans who wanted Hawain annexed to the United States; and in the 1890's they formed the Annexation Club. ${ }^{103}$ In 1893, when Queen Liliuokalani threatened to proclaim another constitution increasing the crown's power, ${ }^{104}$ the American merchant community organized to overthrow the monarchy. Even after the Queen had clearly abandoned her plan, ${ }^{105}$ the Americans continued their opposition under the naine of the Committee of Public Safety. On January 16, 1893, John L. Stevens, the United States Minister in Hawaii and a long-term friend of the annexationists, ${ }^{106}$ ordered marines to land in Honolulu. His excuse for imvading was to protect American citizens and property. ${ }^{107}$ The insurrectionists proclaimed a provisional governinent which Stevens recognized even before the Queen's chief lines of defense liad surrendered. The Queen realized that her forces could not defeat the armed merchants and the Umited States Marines. In order to prevent futile bloodshed, she relinquished her governmental authority. The reaction on the mainland against Umited States military involveinent in the revolution temporarily prevented the annexation which the merchant revolutionaries had planned. ${ }^{108}$ The provisional government therefore established the Republic of Hawain, which lasted until annexation in 1898.

99. Constitution of 1887 , art. 59, in Thurston at 189.

100. Constitution of 1887 , art. 56, in Thurston at 188.

101. Constitution of 1887, art. 59, in Thurston at 189.

102. Constitution of 1887 , art. 62 , in Thurston at 190 .

103. AMERICAN EXPANSION, supra note 95, at 206-08.

104. See U.S. AND THE HAWAIIAN KINGDOM, supra note 95, at 155-91.

105. Id. at 173.

106. AMERICAN EXPANSION, supra note 95, at 187.

107. See U.S. AND THE HAWAIIAN KINGDOM, supra note 95, at 176.

108. For example, President Cleveland, in refusing to submit a treaty of annexation to the Senate in 1893, pointed to the unethical role the United States had played.

But for the notorious predilections of the United States Minister for Annexation, the Committee of Safety, which should be called the Committee of Annexation, would never have existed.

But for the landing of the United States forces upon false pretexts respecting the danger to life and property the committee would never have exposed themselves to the pains and penalties of treason by undertaking the subversion of the Queen's Government.

But for the presence of the United States forces in the immediate vicinity and in position to afford all needed protection and support the 
The constitution of the Republic expropriated ${ }^{109}$ the Crown lands, without compensation to the monarch, ${ }^{110}$ and made them available to Westerners for purchase. Although leaving Mahele lands to the descendants of lesser chiefs and their transferees, ${ }^{111}$ the Western minority had secured control over another vast part of Hawain. The Land Act of $1895^{112}$ provided for the disposition of some former Crown lands as homesteads. ${ }^{113}$ Only citizens could apply for homesteads ${ }^{114}$ and the exclusion of most Orientals from citizenship ${ }^{115}$ limited homesteading to Hawaiians and Westerners. ${ }^{116}$ The portion of the Act most suited to Native Hawaiians provided for 999-year leases of small acreage at no cost. $^{117}$ The leases, however, were malienable and could not be de-

committee would not have proclaimed the provisional government from the steps of the Government building.

President's Message Relating to the Hawaitan Islands, H.R. Exec. Doc. No. 47, 53d Cong., 2d Sess. XIII (1893).

109. See constitution of 1894, art. 95, [1895] Hawaii Laws 118, in Thurston at 237.

110. Queen Liliuokalani brought suit against the United States for compensation, but this claim was denied. Liliuokalani v. United States, 45 Ct. Cls. 418 (1910).

111. King Kanrehameha III had separated his private lands from those of the government to safeguard them from Western takeover. In debate in the Privy Council, June 6,1848 , G.P. Judd had stated that it was necessary for the King to divide his private lands from the lands of the government because, "If no explanation of this kind is made, it will mix matters later on, and sone of the foreigners will come later on and say they have an interest in the lands too." Debates of the Privy Council in 1848 at 42, June 6,1848 , on file in Hawaii State Archives.

112. Act of August 14, 1895, Act 26, [1895] Hawaii Laws Spec. Sess. 49-83.

113. Homesteading had been previously provided for by Act of August 29, 1884, ch. 45, [1884] Hawaii Laws 86, im Revised LAws 1925 at 2200 . However, only 527 homesteads were taken out under this previous act and subsequent amendments, and of those only 337 were patented. HOUSE COMM. ON THE TERRITORIES GOVERNMENT FOR THe TerRitoRy of HAWAII, H.R. REP. No. 305, 56th Cong., 1st Sess. 65 (1900). The 1895 Land Act provided for continued auction sales of land, but limited the size of parcels to 1000 acres. Act of August 14, 1895, Act 26, \$17, [1895] Hawaii Laws 56.

114. Act of August 14, 1895, Act 26, $\$ 31$ [1895] Hawaii Laws Spec. Sess. 62.

115. Constitution of 1894, art. 17-18, [1895] Hawaii Laws 79, in Thurston at 205206. The constitution provided citizenship for only those Orientals born or naturalized in the Republic of Hawain. The effect of this naturalization requirement was to exclude most Orientals from homesteading eligibility.

116. The Land Act was conceived by plantation owners as a nieans to attract white labor and to prevent an Oriental takeover by the Chinese and Japanese plantation workers they had imported. See essays by Hawaiian President Sanford B. Dole in 2 HAWanAN Kingdom, supra note 95, at 192. Dole wrote, "The problent of population is only to be worked out through far more comprehensive efforts, which shall aim to bring settlers and citizens rather than convicts and coolies . . .."

117. Act of August 14, 1895, Act 26, $\S \S 28-55$, [1895] Hawaii Laws Spec. Sess. 61. The Iand Act of 1895 also provided a right of purchase lease designed for impoverished potential agricultural entrepeneurs (id. $\S \S 59-64$ at 75) and a cash freehold for those who had capital (id. $\$ \S 65-70$ at 78). The Commissioners of Public Land also sold land for caslı plus credit (id. $\$ 17$ at 56) and thus fashioned what have frequently been referred to as "Special Homestead Agreements," primarily with Westerners. 
vised, but would descend to statutory heirs. ${ }^{118}$ An analysis of homesteading in the first years after the Land Act indicates that Native Hawaiians were not the inain beneficiaries. ${ }^{119}$

Changing attitudes in the United States concerning imperiahism permitted Hawaiian annexation in $1898,{ }^{120}$ but annexation did not innediately affect the homesteading progran. Although the joint Newlands Resolution of Annexation ceded all public lands of the Republic of Hawaii to the United States, ${ }^{121}$ it affirmed the validity of "municipal legislation of the Hawaiian Islands"122 and the public land laws of the United States were inade inapplicable to Hawaii. ${ }^{123}$ Ironically, a 1910 amendment to the Organic Act, ${ }^{124}$ which was designed to facilitate the hoinesteading programs, became the precursor of their demise. It directed the Territory to open land in a given locality when 25 or more qualified hoinesteaders apphed for that land. ${ }^{125}$ For the sugar interests, this amendment could not have come at a less opportune time. A large number of long-term leases on crown lands were due to expire during the 1920's and 1930's, and thus could become open to homesteading under the 1910 amendment. ${ }^{126}$ For example, a prime sugar tract previously leased to the Waiakea Mill Company near Hilo had been opened to hoinesteading in 1918. ${ }^{127}$ Although the Mill Company leased back virtually all the land within several years, the industry undoubtedly wished to avoid the costs of regaining homestead land.

An entirely different problem provided the rationale for legislation to protect the sugar industry fron honesteading. During this period,

118. Act of August 14, 1895, Act 26, $\$ 43$, [189.5] Hawaii Laws Spec. Sess. 67. Under Public Law No. 746 (1950) these 999-year leases can be converted to fee at the holder's option. Act of Sept. 1, 1950, ch. 833, 64 Stat. 572, as amended, Act of Aug. 23, 1954, cl. 824, 68 Stat. 764.

119. HISTORICAL ANALYSIS, supra note 95, at 11, 14.

Although homesteading continued into the twentieth century, the initial benefits to Hawaiians were ultimately lost. By 1951, fewer than 10 percent of the homestead leases remained in Native Hawaiian hands. G. LUTER, REPORT ON HoMESTEADING IN HAWAII 1839-1961 (Jan. 3, 1961) at 15, on file Hawaiian State Dept. of Land and Natural Resources. The lack of capital to fulfill the development condition of the leases and the ban on testamentary disposition were partly responsible for these relinquishments.

120. AMERICAN EXPANSTON, supra note 65, at 293-99.

121. Joint Resolution of July 7, 1898, No. 55, 30 Stat. 750 (1898).

122. Id. $\S 1$.

123. The Newlands Resolution had transferred fee title to the United States but the Territorial Government interpreted the Resolution as allowing continued disposal of public lands. The Organic Act specifically validated those problematic transactions, but it did not significantly affect homesteading. Act of April 30, 1900, ch. 339, \$\$ 73, 91, 31 Stat. 141 .

124. Act of May 27, 1910, ch. 258, § 5, 36 Stat. 443.

125. Id. 36 Stat. 443,446 .

126. See generally Report of the WaIAKEa Homestead Commission (1926).

127. Id. at 12 . 
racial consciousness was rising among Hawaiians and part-Hawaiians, and the Hawaiian leadership perceived that the Hawaiians were a dying race. ${ }^{128}$ The Hawaiian Protective Association suggested that Native Hawaiians be "rehabilitated" by removing them from the influences of city tenements and returning thein to the land. ${ }^{129}$ The result was the Hawaiian Homes Commission Act of $1920^{130}$ which, by its terms, purported to mitigate the perceived racial problem. Although the act may be cited as a humanitarian effort for the surviving descendants of au indigenous people, it was enacted by sugar barons who would not tolerate accelerated homesteading. ${ }^{131}$ A deal was struck: some second-class lands would be put aside for Native Hawaiians under the new program and, in return, all cultivated sugar lands would be withdrawn from homesteading. ${ }^{132}$

Although the Commission was authorized to lease parcels to Native Hawaiians for 99 years at nominal rates, ${ }^{133}$ the land inade available was arid and of inarginal agricultural value. ${ }^{134}$ Hawaiians, in many instances several generations removed from agricultural life, were thus to rehabilitate thennselves on land that experienced farmers would not touch. ${ }^{135}$ Furthermore, homesteaders' land rights were limited: they could not sublet, transfer or mortgage the land to non-Hawaiians and they even needed Commission approval to transfer to Hawainans. ${ }^{136}$ Finally, the Act provided little financial assistance to Native Hawaiians desiring to erect homes and begin farming operations. ${ }^{137}$

128. Cf. A. Lind, Hawan's People 17-18 (1955). Hindsight demonstrates that by 1920 , the population of part-Hawaiians was increasing faster than the population of pure Hawaiians was decreasing. Id.

129. M. Vause, Hawaiian Homes Commission Act, 1962 (unpublished thesis in Umversity of Hawaii Library) 119.

130. Act of July 9, 1921, cli. 42, 42 Stat. 108.

131. See generally M. Vause, Hawä̈an Homes Commission Act, 1962 (unpublished thesis in University of Hawaii Library).

132. Withdrawal was authorized by Congress in the Act of July 9, 1921, ch. 42 , §§ 203, 212, 42 Stat. 109, 112.

133. Id. $\S \S 207(\mathrm{a}), 208(2), 42$ Stat. 109-11.

134. Approximately 200,000 acres of public land were "nıade available" to the Hawaiian Honies Commission, which was a branch of the territorial government. Act of July 9, 1921, ch. 42, $\$ 203,42$ Stat. 109. See text accompanying notes 218-52 infra for discussion of current problenis of the Hawaiian Homes program.

135. At that time, Governor McCarthy of Hawaii stated that if better lands were made available to Hawaiiaus, "the main object of the nieasure would be defeated as the Hawaiians would not work the land themselves but would have the work done by Japanese." Letter from Governor McCarthy to Secretary of the Interior Payne, June 30, 1920, in M. Vause, Hawaiian Homes Commission Act, 1962 (unpublished thesis in Uriversity of Hawaii Library) 117.

136. Act of July $9,1921, \mathrm{ch} .42, \S 208(5), 42$ Stat. 111.

137. The Commission could lend prospective honiesteaders up to $\$ 3,000$. Id. $\S \S$ 214-15, 42 Stat. $111,112$. 
In return, the Organic Act was amended to provide that non-homestead leases of public land would be for 15 years and that those leases could not be withdrawn to meet new demands for homestead leases. ${ }^{138}$ Since no one could outbid the sugar interests for these leases, the industry obtained the use of the best lands in Hawaii. In fact, the sugar mterests had bought virtually permanent use of government-owned sugar lands. Homesteading, except by Native Hawaiians under the Hawaiian Homes prograin, came to an end. ${ }^{139}$ Poorer Caucasians and Hawaiianborn Orientals, who as Umited States citizens would have been eligible for homesteading, were demed access to public lands since only persons possessing "not less than one-half part of the blood of the races inhabiting the Hawaiian Islands previous to $1778^{\prime 140}$ were eligible under the Act.

II

\section{Present Land Problems of Native Hawautans}

Almost 20 percent of Hawaii's population has some Native Hawaiian ancestry. ${ }^{141}$ Great variation in wealth and degree of assimilation exists among Native Hawaiians, but generally that community is one of the poorest ethnic groups within the State today. ${ }^{142}$ As real estate values in Hawaï rise, the number of geographic areas in which Native Hawaiians are able to purchase land or can afford to live decreases. Since Native Hawaiian culture has been tied to the land, ${ }^{143}$ a land base is necessary for those Hawaiians who choose a traditional way of life. In addition, sufficient urban lomeland must be assured so that economic necessity will not force Native Hawaiians to leave the Islands that form the basis of their cultural identity. ${ }^{144}$

In exploring possible methods to preserve and increase the land base of Native Hawaiians, this section will focus on the problems faced by Native Hawaiian kuleana lolders: these problems are representative of those confronting other Native Hawaiian owners of small acreage fee interests. The section will then examine the Bishop Estate and the Hawaiian Homes program, the two most importaut potential land bases

138. Compare Act of April 2, 1908, ch. 124, 35 Stat. 56 with Act of July 9, 1921, ch. $42, \S 304,42$ Stat. 117.

139. From 1921 to 1946 only one tract of land was opened for general homesteading. Hawait (Territory) Land Laws Revision Commission, Final Report 44 (1946).

140. Act of July 9, 1921, ch. 42, § 201(a)(7), 42 Stat. 108.

141. See T. Fisher, Hawait: Growing Pains in Paradise 12 (1973).

142. See generally D. Tuttle, Hawaii Voting Behavior: A Guide to Estimated Social and Economic Characteristics, 1972 (unpublished thesis in University of Hawaii Library).

143. See generally Handy, Handy \& Pukui, Native Plantens in Old Hawaii, in BeRNICE P. BISHOP MUSEUM Bull. No. 233.

144. Today most Native Hawaiians live in or near Honolulu. STATE of HAWAI, The State of Hawail Data Book, A Statistical Abstract 8 (1974). 
for Native Hawaiian utilization. Finally, it will analyze the current land reparation claim of Native Hawaiians.

\section{A. Protection of Kuleana Rights}

Despite the loss of many kuleana, ${ }^{145}$ a significant number are still held by Native Hawaiians, particularly in rural areas such as East Molokai. Inherited kuleana constitute an important source of land held in fee by impoverished Native Hawaiians. ${ }^{146}$ These plots, and the gathering rights they confer, ${ }^{147}$ have provided adequate hoinesites for nuclear or extended Hawaiian families. However, three major legal obstacles bar full use of many kuleana.

\section{Fractionated Ownership}

A kuleana that one person received in the 1850's may now be owned by dozens of individuals if, in the intervening generations, the property passed by intestate succession. ${ }^{148}$ Although each joint owner has a legal right to enter and use the land, ${ }^{149}$ no one has inuch incentive to improve the land or pay taxes ${ }^{150}$ if title is so clouded that ownership is perceived as only temporary. Even if estate counseling were feasible and effective for the future, legal assistance would be necessary to untangle those kuleana interests which are already fractionated.

If the number of joint owners is relatively small, there are three possible remedies. First, one joint owner can buy out the others. Second, the kuleana can be partitioned and each joint owner given title to a

145. Several studies indicate how few kuleana were retained by Native Hawaiiaus. One estimate is that no inore than one-third of the 937 kuleana on Kauai were securely held by Hawaiians in 1915. J. Lydgate, The Vanishing Kuleana, in Thrum's HawaIIAN Almanac and ANNUAL For 1915 at 109. Although the percentage was likely to have been greater on the outer islands, a recent survey indicated that in densely populated Oahu less than 6.6 percent of the kuleana were still in Hawaiian hands as of 1936 . IsLAND COMMUNTTY, supra note 1, at 49.

146. Interview with Fred Bicoy, West Molokai Community Advisor, Office of Economic Opportunity, in East Molokai, July 27-29, 1973.

147. The ahupuaa historically ran from the mountains to the sea, with gathering rights for residents extending throughout this area. Today, lawful occupants of kuleana retain these rights. They may take firewood, house timber, aho cord, thatch and ki leaf for their own use. HAwaIl REv. StaTs. \$ 7-1 (1968).

148. As with mainland Indians, the imposition of a foreign inheritance scheme has led to ownership patterns neither traditional nor typical of Western landholding. See Comment, Too Little Land, Too Many Heirs-The Indian Heirship Problem, 46 WASH. L. REv. 709 (1971).

149. See Moranho v. De Aguiar, 25 Hawaii 267, modified, 25 Hawaii 271 (1920); Lui v. Kaleikini, 10 Hawaii 391 (1896).

150. The nonpayment of taxes is a recurrent cause of loss of kuleana. Interview with Fred Bicoy, East Molokai Commuuity Adviser, Office of Economic Opportunity, in East Molokai, July 28, 1973. 
portion of the land. ${ }^{151}$ Finally, if joint owners prefer to retain undivided ownership, title can be assigned to a mutually-owned corporation, trust, or partnership with the power to assure payment of taxes and to enforce agreed-upon land use patterns.

The owners of a kuleana, however, may be so numerous as to render the latter two solutions infeasible. Effective use of the land may require one or more of the joint owners to purchase the interests of others. The risk inherent in this approach is that impoverished Native Hawaiians may lose their only access to land ownership as they are bought out by more financially able Hawaiians. Only infusion of money from government or charitable sources will allow financially needy jomt owners to undertake acquisition. Perhaps if kuleana ownership is viewed as a base of self-support for people who might otherwise need continual financial assistance, public funding is politically possible.

\section{Inadequate Access}

Since large plantations and developments surround kuleana, many roads leading to them are indirect or in such poor condition as to render them impassable to inodern transportation. Legal tools already exist to remedy this problem: the doctrine of easements by necessity, for example, has been consistently recognized by Hawaiian courts. ${ }^{162}$ In applying this doctrine, the courts have not required prior ownership by a simgle person of both the servient and donimant estates, ${ }^{163}$ nor, if the property is landlocked, have they required that the right-of-way be absolutely necessary. ${ }^{154}$ The easement inust be "reasonably" necessary; that is, other access inust be either difficult or expensive to use. ${ }^{165}$ Thus, convenient right-of-way presently used by a kuleana holder can usually be upheld even if the user cannot establish a prescriptive easement.

In addition, statutory sanction exists for rights-of-way to kuleana. Hawaiian law still retains the 1850 statute establishing kuleana, which declares that, "the people shall have . . . the right of way. . . . The roads shall be free to all, on all lands granted in fee simple." "160 This provision has been used as historical evidence to strengthen the theory

151. HAWAII REV. Stats. $\S 668$ (1968) provides procedures for partition of real estate. Of course, compliance with zoning laws concerning subdivision of property would also be necessary.

152. See Palama v. Sheehan, 50 Hawaii 298, 440 P.2d 95 (1968).

153. Henry v. Ahlo, 9 Hawaii 490 (1894).

154. Palama v. Sheehan, 50 Hawaii 298, 301, 440 P.2d 95, 98 (1968); Enos v. Wa Sing, 4 Hawaii 457 (1882).

155. See, e.g., Kalaukoa v. Keawe, 9 Hawaii 191, 193 (1893).

156. HaWAII Rev. Stats. $\S 7-1$ (1968) (originally enacted as Act of August 6, 1850, § 7, [1850] Hawaii Laws 202); ReVISED LAws 1925 at 2142. 
of right-of-way by necessity. ${ }^{157}$ It should also be used as an independent ground to establish access to land. There is precedent using ancient Hawaiiau custoin and usage to determine nnodern property rights. For example, the court has considered the purpose of laws enacted at the time of the Great Mahele in order to resolve a current water rights issue. ${ }^{158}$ Since the problems of the kuleana also stems from the Great Mahele, a similar approacli should be taken to preserve access. ${ }^{159}$

\section{Adverse Possession}

Fractionated ownership and lack of access often lead to disuse of kuleana plots which, in turn may lead to permanent loss of possessory rights through adverse possession. The doctrine of adverse possession demies to the legal owner of land the ability to use the courts to eject one who has occupied that land for a statutory period ${ }^{160}$ in an open, hostile, notorious, and exclusive manner. ${ }^{161}$ Doctrines developed in other jurisdictions that would stay this trend, and limit the application of adverse possession, have not been adopted in Hawani. ${ }^{162}$ Rather, adverse possession has been used primarily by large landholders to absorb the enclosed kuleana of Native Hawaiians. ${ }^{163}$ Although a large

157. Palama v. Sheehan, 50 Hawaii 298, 300, 440 P.2d 95, 97 (1968).

158. McBryde Sugar Co. v. Robinson, 54 Hawaii 174, 504 P.2d 1330, aff'd on rehearing, 55 Haw. 260, 517 P.2d 26 (1973), appeal dismissed, 417 U.S. 962 (1974).

159. Traditional rights of kuleana owners might also be used to control resource-destructive aspects of development and to extend rights-of-way throughout the ahupuaa to reach the mountains and beaches. It could be argued that since the people have rights to gather resources within the ahupuaa, any future development that would destroy these natural resources must be halted. See note 147 supra.

As a modest note, the legislature passed a public access statute, HaWAn REV. STATs. $\$ 46-6.5$ (a) (1968). It provides that all developers, as a condition precedent to final approval of a subdivision where public access is not already established, must dedicate land for public access from public highways to the coastal shoreline, mountain trails, and existing facilities for hiking, hunting, fruit-picking, ti-leaf sliding, and other recreational purposes. See Comment, Hawaiian Beach Access: A Customary Right, 26 HASTINGS L.J. 823 (1975).

160. Hawait Rev. STats. $\S \S 657-31,669-1$ (1968). The statute of limitations was originally 20 years. Act of July 18,1870 , ch. $22, \S 1$, [1870] Hawaii Laws 28 . This period was reduced to 10 years in 1898. Act of April 22, 1898, Act 19, $\$ 1$, [1898] Hawaii Laws 22. See note 165 infra for the 1973 amendment which changed the period back to 20 years.

161. For example, Hawaiian courts have not been strict in demanding that the adverse possessor enter under claim of title. See Deponte v. Ulupalakua Ranch, Ltd., 47 Hawaii 17, 395 P.2d 273 (1964); Lalakea v. Hawaiian Irrigation Co., 36 Hawaii 692 (1944). Nor have they always required the adverse possessor faithfully to pay taxes. See Gomes v. Upchurch, 50 Hawaii 125, 432 P.2d 890 (1967); Deponte v. Ulupalakua Ranch, Ltd., 48 Hawaii 17, 395 P.2d 273 (1964).

162. Thomas v. State, 55 Hawaii 30, 514 P.2d 572 (1973); Oahu Ry. and Land Co. v. Kaili, 22 Hawaii 673 (1915); Booth v. Beckley, 11 Hawaii 518 (1898).

163. See Town \& Yuen, Public Access to Beaches in Hawaii, "A Social Necessity," 10 HAWAI B.J. 5, 21 (1973). 
landholder cannot gain title by merely showing non-use of the $k u$ leana, ${ }^{164}$ it may be relatively easy to cultivate the lands of an enclosed kuleana and to begin occupying the land through adverse possession. Reduction of adverse possession claims to paper title is then a simple matter $^{165}$ and opens the door to development. Native Hawaiians have been less able to use the doctrine to secure land for themselves. For example, if a native tenant remained on cultivated lands after 1850 , but never applied for a kuleana, his continued possession was deemed permissive rather than adverse. ${ }^{166}$ Thus it becaune practically impossible for a commoner to adversely possess land owned by a konohiki.

There are two approaches for kuleana owners who want to avoid this loss. One alternative, suggested by Chief Justice William Richardson of the Hawaii Supreme Court, is that more Native Hawaiians register their lands to prevent thein from being taken by adverse possession. ${ }^{167}$ A second approach is Native Hawaiian pressure to reform the adverse possession laws. In 1973, the statutory period for adverse possession was changed froin 10 to 20 years, ${ }^{168}$ thus allowing land owners a longer period in which to evict a potential adverse possessor. The legislature also passed a bill which would have required an adverse claimant to have entered the land in good faith. ${ }^{100}$ Although this bill would merely have prevented successful claims by those who had not acted in good faith, it was vetoed by the governor. ${ }^{170}$

\section{B. The Bishop Estate}

The Bishop Estate ${ }^{171}$ is the largest and most important of Hawaii's landed charitable estates. ${ }^{172}$ Its holdings on all major Islands except

164. Akowai v. Lupong, 4 Hawaii 259 (1880).

165. Title can be established pursuant to the Land Court Registration Act, HAwsI Rev. STars. $\$ 501$ (1968), Hawaii's enactment of the Torrens System. That Act has had very limited use because of its complex procedures; an application must include a boundary survey and a complete abstract of title. Expense, in fact, limits use of the Act to wealthy landowners and large developers. Most landholders rely instead on actions to quiet title, which are simple to bring, especially when unopposed. HAwAm REv. STATs. $\S 669$ (1968). See D. Dauthet, Clearing Land Titles in Hawaii, Sept. 23, 1974 (unpublished paper).

166. See, e.g., Dowsett v. Maukeala, 10 Hawaii 166 (1895).

167. Hawaii Advertiser, Feb. 9, 1974, at A-2, col. 1.

168. HaWAII Rev. Stats. \& 657-31 (Supp. 1974).

169. H.B. 15, S.B. 879, Reg. Sess. (1973); legislative passage, April 11, 1973.

170. Governor's veto, June 1, 1973. Seventh Legislature of the State of HAwaI, Final Status of Bills and Resolutions 202 (1974).

171. See text accompanying notes 83-85 supra for discussion of the fornation of the Bishop Estate.

172. Other major landed charitable estates include Queen's Hospital, Queen Liliuokalani Trust, and The Bernice P. Bishop Museum. See R. Horowntz, Public LaNd Policy IN HAWAIr: MAJOR LANDOWners 17 (Legislative Reference Bureau Report No. $3,1967)$ [heremafter cited as MAJOR LANDOWNERS]. 
Lanai comprise nine percent of the state. ${ }^{173}$ The will of Princess Bernice Pauahi Bishop established the Estate and named five Westerners as trustees; their successors were to be named by the members of the Hawaii Supreme Court. ${ }^{174}$ The trustees were authorized "to sell and dispose of aury lands of the . . . estate and to excliange lands and otherwise dispose of the same" to further the trust purposes. ${ }^{175}$ Approxinrately 90 percent of the Estate's land is leased for long terms for residential, agricultural, commercial, and industrial purposes. ${ }^{176}$ But the Estate has failed to put its resources to effective use. Although the Estate's total landholdings are valued conservatively at more than $\$ 500$, $000,000,{ }^{177}$ its annual income is under $\$ 9,000,000,{ }^{178}$ or less than two percent of its capital. Such a minimal return raises the question of whether the trustees are fulfilling their statutory obligation to manage the Estate in the "manner in which men of ordmary prudence, discretion, and judgment would act in the management of their own affairs."179

More inportautly, the low return has prevented the Estate from realizing its benevolent aims. Princess Bisliop's will directed the trustees to hold the corpus upon the following trusts: to maintain two schools, and to support orplians and other indigents, "giving the preference to Hawaiians of pure or part aboriginal blood. . . ."180 Despite

173. Id. at 17,44 .

174. Will of Princess Bernice Pauahi Bishop, para. 14, Equity file No. 2048 (Hawaii Cir. Ct., Ist Cir. Dec. 2, 1884).

For the decision that Justices, when appointing Trustees, are acting as individuals rather than as members of the judiciary, see Kekoa v. Supreme Court, 59 Hawaii 174, 516 P.2d 1239 (1973); In re Bishop Estate, 23 Hawaï 575 (1917), aff'd, 250 F. 145 (9th Cir. 1918).

175. Will of Princess Bernice Pauahi Bishop, para. 13, Equity file No. 2048 (Hawaii Cir. Ct., 1st Cir. Dec. 2, 1884). Codicil No. 1, para. 17 further states: "I give unto the trustees named in my will the most ample power to sell and dispose of any lands or other portions of my estate . . . but [direct them] to continue and manage the same, unless in their opinion a sale may be necessary for the establishment or maintenance of said schools, or for the best interest of my estate." Quoted in Midkiff v. Kobayashi, 54 Hawaii 299, 330, 507 P.2d 724, 742 (1973).

176. MAJOR LANDOWNERS, supra note 172, at 20, 23-24.

177. The Bishop Estate reported the basis of its tax assessment of July 1, 1972 was $\$ 360,592,000$. See Honolulu Advertiser, Aug. 1, 1973, at A-7, col. 1. The state assesses property at $70 \%$ of real market value. Property TeChNiCal OfFice, DeP'T of 'TaXation, Hawam's Assessment-Sales Ratto Study 1973 at 1 (1974). Coinpare for example, the endowment of Stanford University at $\$ 365,000,000$, STANFORD UNIVERSITY, FACTS: STANFORD UNIVERSITY, 1973-1974, and the Carnegee Corporation at \$284,000,000, M. LeWIS, The Foundation Directory 258 (1971).

178. "In 1971-1972 the annual rents totaled $\$ 8,775,805$. There was additional income of $\$ 666,968$, from interest, dividends and other sources." Honolulu Advertiser, Aug. 1, 1973, at A-7, col. 1.

179. Hawam Rev. Stats. \$ 557-2(a) (3) (Supp. 1974).

180. Will of Princess Bernice Pauahi Bishop, para. 13, Equity file No. 2048 (Hawaii Cir. Ct., 1st Cir. Dec. 2, 1884), cited in In re Bishop Estate, 53 Hawaii 604, 609-10, 499 P.2d 670, 674 (1972). 
this broad directive to support and educate indigent Native Hawaiians, the Estate has limited its activities almost exclusively to maintaining the Kamehameha Schools. ${ }^{181}$ Moreover, the Kamehameha Schools receive only 85 percent of their expenses froin the Estate; the balance is collected in tuition from students-all of whom are part-Hawaiian. ${ }^{182}$

To coinbat the low return on its capital, the Estate has begun to lease large tracts of land to private compames which develop and sublet that land. These transactions, however, have sparked resentment among those Native Hawanians who no longer believe that developinent is always beneficial. In 1969, for example, a broad-based political coalition opposed the eviction of a pig farmer from Bishop Estate land slated by the trustees for a Kaiser Aetna development. ${ }^{183}$ It is ironic and unfortunate that a charitable estate would have prevented a traditional Hawaiian activity in order to produce revenue to educate Native Hawanians. During the past five years, the Estate has attempted to raise capital by large acreage sales. ${ }^{184}$ A 1970 sale of 2,300 acres to a developer was set aside as against the best interest of the Estate, because the trustees had not insured that the sales price was adequate. ${ }^{185}$ In 1973, the Estate agreed to sell 15,000 acres on the island of Hawaii for $\$ 6,200,000,{ }^{186}$ a price of about $\$ 413$ an acre.

The trustees have attempted to minimize public inquiry about Estate finances by pointing to the difficulties of running a tax-exempt foundation. ${ }^{187}$ Their activities are shrouded in an accounting system that has been described as difficult to understand; ${ }^{188}$ and, in the past,

181. Zalborg, Bishop Estate-Kam Schools Relations, Honolulu Advertiser, Aug. 1, 1973, at A-7, col. 1 .

182. Statement of Trustee Matsuo Takabuki in Honolulu Advertiser, July 31, 1973, at A-13, col. 1; The Kamehameha Schools, Providing Education Services for Hawaii's Youth (1973) (brochure to parents from the schools).

183. See R. Pedersen, The Ad Hoc Committee for a Hawaiian Trustee 28, August, 1972 (unpublished thesis in University of Hawaii Library) [hereinafter cited as Pedersen].

184. Nevertheless, the trustees recently claimed that tax consequences made the sale of small plots of Estate land prohibitive, thereby justifying their low cash flow. Hawaiian Advertiser, Aug. 1, 1973, at A-7, col. 1.

On the other hand, in the early 1960's, the Estate vigorously opposed legislation that would have allowed long-term lessees of residential property to purchase the remainder interests in leased lands. See, e.g., H.B. 16, Reg. Sess. (1961). For discussion of the political battle see R. HoRowitz \& N. MilleR, LAND AND Polrtics IN HAwnII (1963). The Estate marshaled Native Hawaiian opposition to the legislation by pointing to the potential shrinkage of Estate holdings. See generally Pedersen.

185. Midkiff v. Kobayashi, 54 Hawaii 299, 329-34, 507 P.2d 724, 743 (1973).

186. Honolulu Star-Bulletin, July 11, 1973, at A-1, col. 2.

187. Zalborg, Bishop Estate-Kam Schools Relations, Honolulu Advertiser, Aug. 1, 1973, at A-7, col. 1 .

188. Report of the Master on the Petition of the Trustees for Approval of the 83rd Annual Report at 30, Equity file No. 2048 (Hawaii Cir. Ct., 1st Cir. Sept. 25, 1970) [hereinafter cited as Master's Report]. 
they have breached their legal obligation to publish annually a list of the Estate's assets in a Honolulu newspaper. ${ }^{189}$

The trustees could amplify the Estate's benefits to Native Hawaiians, consonant with the Bishop will, by making land available directly to Native Hawan̈ans. The Estate's sale of land to developers for \$413 an acre indicates that the same or coinparable land could have been made available to Native Hawan̈an groups at a similar rate. Although the price may have been inadequate for a third party, it is arguably proper for a beneficiary. ${ }^{190}$ This procedure would ease the problems of landless Native Hawaiians without lessening Estate revenues. Furthermore, the will directed the trustees to "devote a portion of each year's income to the support and education of orphans, and others in indigent circumstances, giving the preference to Hawaïans. . . ."191 Case law is clear that trustees have latitude in implementing the intent of the testator as determined froin a will in its entirety. ${ }^{192}$ Under this authority the Estate could support indigent Native Hawaiians by leasing land to thein at a nominal rate. In a narrower application of this principle, land and hoines could be made available to indigent parents of students and potential students of the Kamehameha Schools. ${ }^{193}$

Since trustees have enormous discretion under the will, lawsuits probably cannot force them to take innovative action such as allowing Native Hawaiians free use of Estate land or deciding against development projects that might disrupt Native Hawan̈an communities. Action by the trustees themselves is the best hope for such policy changes. The appointment of trustees sympathetic to the needs of Native Hawaiians is the surest means of effecting major changes within the Bishop Estate. Consequently, the Native Hawaiian community has attempted to reform the appointment of trustees. In 1971 the Ad Hoc Committee for a Hawaiian Trustee was formed to prevent the appointment of a non-Hawaiiall to fill a vacancy on the Board of Trustees. ${ }^{194}$ Although both the political movement and corollary lawsuits ${ }^{195}$ were unsuccessful, when another vacancy opened up in 1974, the Supreme Court appointed a Native Hawaiian to the position. ${ }^{196}$

189. In re Bishop Estate, 16 Hawaii 804 (1905).

190. See text accompanying note 193 infra.

191. Will of Princess Bernice Pauahi Bishop, para. 13, Equity file No. 2048 (Cir. Ct., 1st Cir. Dec. 2, 1884); cited in In re Bishop 'Estate, 53 Hawaii 604, 609-10, 499 P.2d 670, 674 (1972) (emphasis added).

192. See Estate of Weill, 48 Hawaii 553, 406 P.2d 718 (1965); Hawaiian Trust Co. v. Breault, 42 Hawaiu 268 (1958).

193. For a discussion of the interrelation of poverty and education, see C. JENCKS, INEQUALITY-A REASSESSMENT OF THE EFFeCT OF FaMILY aND Schooling IN AMERICA (1972).

194. See generally Pedersen, supra note 183

195. Kekoa v. Supreme Court, 53 Hawaii 174, 516 P.2d 1239 (1973).

196. Honolulu Star-Bulletin, Aug. 14, 1974, at A-1, col. 5. 
However, lawsuits by Native Hawaiiaus are a proper means of enforcing the trustees' non-discretionary duties to account aud to make the trust productive. ${ }^{197}$ To date, Native Hawaiians have been reluctant to prosecute such suits for fear that, if brought into issue, the entire Estate program might be challenged as granting an unconstitutional preference on the basis of race. This concern was exacerbated in 1972 by a concurring opinion in all appeal to the Hawaii Supreme Court from a routine order approving an accounting by the trustees. ${ }^{108}$ Justice Abe took the occasion to opine that the Bishop will does not require the Estate to prefer Native Hawaiians for admission to Kamehameha Schools, ${ }^{199}$ even though this interpretation of the will conflicts with that of the origmal trustees, including the testator's husband. ${ }^{200}$ Moreover, the opinion concluded that such a preference for Native Hawaiians would be unconstitutional. ${ }^{201}$ The inajority refused to discuss the question of preference since it had not been raised at the trial. ${ }^{202}$ However, the issue will surely be judicially considered in the future.

Interpreting the will to require preference for Native Hawaiians in admission to the Kamehameha Schools raises the question of the constitutionality of such a provision in a charitable trust. The Equal Protection Clause of the Fourteenth Ameudment forbids discrimination against a racial minority by a private school estabhished by a state-administered will. ${ }^{203}$ The Umited States Supreme Court has not yet decided whether providing special benefits to all economically disadvan-

197. The Hawaiian Supreme Court has assumed without discussion that Native Hawaiians, as special beneficiaries of the Estate, have standing to sue. See, e.g., Kekoa v. Supreme Court, 53 Hawaii 174, 516 P.2d 1239 (1973); see also 4 ScotT on Trusrs $\S 391$ (2d ed. 1956). The Attorney General of the State also has authority to bring suit to protect the interests of beneficiaries of charitable estates. See Midkiff v. Kobayashi, 54 Hawaii 299, 335, 507 P.2d 724, 745 (1973).

198. In re Bishop Estate, 53 Hawaii 604, 499 P.2d 673 (1972).

199. He stated that the will

provides simply for the erection of "two schools, each for boarding and day scholars, one for boys and one for girls ...." The only racial limitation is contained in the direction "to devote a portion of each year's income to the support and education of orphans, and others in indigent circumstances, giving preference to Hawaiians of pure or part aboriginal blood . . ."

Id. at 610,494 P.2d at 674 (Abe, J., concurring).

200. SHOAL OF TIME 299-301.

Although the interpretation of the will by Bernice's husband as trustee is not binding on a court, much is known of the allegiance which Bernice, the last of the Kamehameha line, felt towards Native Hawaiians. See H. Kent, Chardes REed Bishop: Man of Hawain (1969); C. Black \& K. Mellen, Prencess Pauahi Bishop and Her LEGACY (1959). Her testamentary intent would be carried out most faithfully by interpreting the preference clause as referring to all the charitable aims of the Estate.

201. 53 Hawaii at 611,499 P.2d at 674 .

202. Id. at 608, 499 P.2d at 673 .

203. See, e.g., Pennsylvania v. Board of Trusts, 353 U.S. 230 (1957) (The Girard College Case). See also Lusky, National Policy and the Dead Hand: The Race Conscious Trust, in 112 TRUST AND Estates 554 (1973). 
taged minority groups can justify racial criteria in admissions. ${ }^{204}$ Even if such programs are generally declared unconstitutional, ${ }^{205}$ the Bishop Estate program should be considered constitutional as reasonably related to a legitimate concern for an indigenous people.

United States statutes and case $1 \mathrm{aw}^{206}$ have traditionally applied special rules to American Indians. Congress has passed Indian legislation in the fields of education, ${ }^{207}$ health, ${ }^{208}$ civil liberties, ${ }^{209}$ and general welfare. $^{210}$ Morton $v$. Mancari ${ }^{211}$ upheld a statute ${ }^{212}$ which required that Indians be preferred for employment within the Bureau of Indian Affairs. The Court specifically enunciated what had been implicit in earher decisions: ${ }^{213}$ Indian legislation is constitutional if ". . . the special treatment can be tied rationally to the fulfillment of Congress' unique obligation toward the Indians ...."214 Although Native Hawaiians cannot properly be called "American Indians" in an anthropological sense, the plight of both groups as indigenous peoples within the United States calls for analogous legal treatment. ${ }^{215}$ The phrase "Hawaiians . . . of pure or part aboriginal blood"216 in the Bishop will is not as exclusive as the term "white." Our society tends to define one as white only if he or she has no other identifiable racial ancestry.

204. In the past term, the Court ruled moot a case which challenged an admission policy designed to increase minority enrollment at a law school. DeFunis v. Odegaard, 416 U.S. 312 (1974).

205. For arguments supporting the necessity for and constitutionality of minority admissions programs, see Bell, In Defense of Minority Admissions Programs: A Response to Professor Gaglia, 119 U. PA. L. REv. 364 (1970); Morris, Equal Protection, Affirmative Action and Racial Preferences in Law Admission: DeFunis v. Odegaard, 49 WASH. L. Rev. 1 (1973). For a general discussion of considering race in order to correct racial imbalance and discrimination, see Vieria, Racial Imbalance, Black Separatism, and Permissible Classification by Race, 67 Mich. L. Rev. 1553 (1969).

206. See, e.g., Morton v. Mancari, 417 U.S. 535 (1974); Board of Comm'rs v. Seber, 318 U.S. 705 (1943).

207. See, e.g., 25 U.S.C. $\S 452$ (1970), formerly Act of Apr. 16, 1934, ch. 147, $\S$ 1, 48 Stat. 596.

208. 42 U.S.C. $\$ \S 2001-2005$ (f) (1970), formerly Act of Aug. 1, 1954, ch. 658, 68 Stat. 674 (Indian Hospitals and Health Facilities).

209. 25 U.S.C. $\$ \$ 1302-1303$ (1970), formerly Act of Apr. 11, 1968, Pub. L. No. 90-284, $\$$ 202-03 (Indian Civil Rights Act).

210. See, e.g., 25 U.S.C. $\$ \S 631-632$ (1970), formerly Act of Apr. 19, 1950, ch. 92, $\S \S 1,2,64$ Stat. 44 (Navaho and Hopi Tribes: Rehabilitation).

211. 417 U.S. 535 (1974).

212. Indian Reorganization Act of 1934, 25 U.S.C. $\$ 472$ (1970).

213. See Board of Comm'rs v. Seber, 318 U.S. 705 (1943); Simmons v. Eagle Seelatsee, 244 F. Supp. 808 (E.D. Wash. 1965).

214. Morton v. Mancari, 417 U.S. 535, 555 (1974).

215. The Unted States Supreme Court has never defined the term "Indian" but has implicitly expanded its meaning to include Alaskan Aleuts and Eskimos, non-Indians under an "anthropological" meaning. See Alaska Pacific Fisheries v. United States, 248 U.S. 78 (1918), aff'g 240 F. 274 (9th Cir. 1917). See also Alaska v. Annette Island Packing Co., 289 F. 671 (9th Cir. 1923).

216. See text accompanying note 180 supra. 
One who has any Hawaïan blood is by definition part-Hawaiian. Thusalthough all of the students at the Kamehameha Schools have some Hawainan blood, 83 percent have Caucasian ancestry, 67 percent have Chinese ancestry, 24 percent have Japanese ancestry, and 10 percent have Filipino ancestry. ${ }^{217}$

In sum, the Native Hawaiian preference regarding admission to the Kamehameha Schools is probably constitutional. Since the issue will undoubtedly be raised, remedial lawsuits aimed at correcting Estate deficiencies should not be avoided for fear that the preference clause will be declared unconstitutional.

\section{Hawaiian Home Lands}

Formed more than fifty years ${ }^{218}$ ago to return Native Hawan̈ans to a pastoral life, the Department of Hawainan Home Lands ${ }^{210}$ has yet to provide the Native Hawainan community with a substantial land base. $^{220}$ Although there are 190,000 acres under its jurisdiction, ${ }^{221}$ less than 15 percent of that acreage is currently under lease to Native Hawaiian homesteaders. ${ }^{222}$ Today, only 69 families live on ranch-size

217. The Kamehameha Schools, Providing Education Services for Hawaii's Youth (1973) (brochure to parents from the schools).

218. See text accompanying notes $126-142$ supra on the formation of the Hawaiian Homes program. Problems of the Department of Hawaiian Home Lands have been extensively studied. See generally D. Clegg, Program Study and Evaluation of the Department of Hawaman Home Lands, State of Hawair (1971) thereinafter cited as Program Study]; H. Doi, Legal Aspects of thie Hawailan Homes Program (Legislative Reference Bureau Rep. No. 1A, 1964) [heremafter cited as LEGAL AsPECTs]; D. Hansen, The Homestead Papers: a Critical analysis of the Management of the Department of Hawaman Home Lands (1971) [hereinafter cited as Homestead Papers]; A. Spitz, Land Aspects of the Hawallan Homes Progrum (Legislative Reference Bureau Rep. No. 1C, 1964) [hereinafter cited as LAND Aspects]; A. SpITZ, Organization and Administration of the Hawaman Homes Program (1963).

219. The Federal government gave title to Hawaiian Homes property to the state in Hawaii Admission Act, Pub. L. No. 86-3, $\$ 5$ (b), 73 Stat. 5 (1959). The name of the administrative organization was then changed from the Hawaiian Homes Commission to the Department of Hawaüan Home Lands. The Department is a state exeeutive branch directed by a Commission, whose seven members are appointed by the Governor and must imclude four Native Hawaiians of at least one-fourth native blood. Hawall Const., Hawaiian Homes Commission Act, 1920, \& 202. Provisions governing the Hawaiian Homes Commission Act are now part of the state constitution as required by the Hawaii Admission Act, $\$ 4,48$ U.S.C. Prec. $\$ 491$ (1970).

220. Doubts of the program's constitutionality were expressed both at the time of its adoption and at the time of statehood. See LEGAL Aspecrs, supra note 218, at 4154. See text accompanying notes 205-217, supra, for a contrary argument.

221. Dunn \& Akinaka, A Land Inventory and Land USE Study for the DepartMENT OF HAWAIIAN HOMES 2-4 (1972) [hereinafter cited as LAND INVENTORY]. There is a disparity between the original acreage established in 1920 and the present tally. See, e.g., Homestead PaPers, supra note 218, at 30. Dunn and Akinaka attempt to answer criticism that there are "missing" homestead lands. LAND INVENTORY at 4.

222. LAND INVENTORY, app., table 2. However, almost 13,000 acres not under individual lease are used for community pastures for homesteaders. 1d. Sce note 235 infra 
parcels and 365 families live on farms, usually of 40 acres. ${ }^{223}$ Over 2,000 lomesteading families have been assigned houselots, some as small as 7,500 square feet, im subdivision communities suclı as Papakolea in urban Honolulu and Kalamaula on rural Molokai. ${ }^{224}$

The Hawaiian Homes program must be considered a failure as measured by its original objective to rehabilitate Native Hawiians by returning them to a farming life. Few of the families living on farmsize parcels actually engage in farming operations. Most have relinquished management of their land to pimeapple companies in return for monthly stipends. ${ }^{225}$ However, the program lias succeeded in providing houselots which save soine Native Hawainans from expulsion due to rising land costs. The houselot program evolved from the political pressures of Native Hawaiian squatters at Papakolea who wished the land they were living on to be brought under Hawaiian Homes jurisdiction.226 Today the greatest demand for honesteads is for urban houselots, ${ }^{227}$ and accounts of twenty-year waits for louselots on landshort Oahu have been documented. ${ }^{228}$

Many explanations can be offered as to why the vast acreage of the Hawaiian Homes program has provided so few homesteads. Some critics have poimted to administrative heavy-handedness and lack of innovative thinking. ${ }^{29}$ The Department itself blames the inferior qual-

for land use of the remainder of Hawaiian Home Lands.

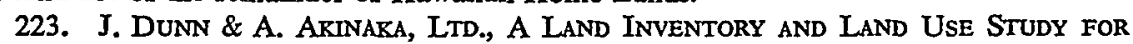
the Department of Hawaitan Home Lands 4 (1972).

224. Department of Hawaitan Home Lands, ANNuAL Report 5 (1973).

225. Homesteaders are not allowed to sublet homesteads. HAwan CONST., Hawaiian Homes Commission Act, 1920, $\$ 208(5)$. However, a series of Attorney General opinions approved arrangements which differ little from subleases. See LEGAL AsPEcTs, supra note 218 at 14-16. The issue may become moot because pimeapple companies are rapidly leaving the Hawaiian Islands. Honolulu Star-Bulletin, Dec. 14, 1973, at C-14, col. 5 .

226. See account in E. Heen, The Hawaiians of Papakolea: A Study in Social and Economic Realistn, 28-31, June, 1936 (unpublished thesis in University of Hawaii Library).

227. Currently over 3,300 Native Hawailans, considerably more than the present number of homesteaders, are on waiting lists for urban lots. DEPARTMENT of HawamaN HOME LANDS, ANNUAL REPORT 4 (1973).

228. See, e.g., Honolulu Advertiser, Dec. 17, 1973, at A-6, col. 1; Honolulu Advertiser, Nov. 13, 1970, at C-3, col. 1.

At present the only way for an applicant to avoid the long waiting list is to receive a homestead through inheritance. If a homesteader dies, the remainder of the 99-year lease can descend or be devised but only to relatives enumerated in HAwaIr CONST., Hawaiian Homes Commission Act, 1920, $\S 209$. Because of the widespread system of hanai, an informal Native Hawainan adoption system, children who have lived with a homesteading family often cannot inherit because they do not have legal standing. See Op. HAWAII ATT'Y GEN. 18 (1973). Another inheritance problem arises under the Act's blood quantum requirement: hoinesteaders inust have at least 50 percent Hawaiian blood. HawaIr Const., Hawaüan Homes Commission Act, 1920, \$ 201(7).

229. See, e.g., HOMESTEAD PAPERS, supra note 218. 
ity of much of its land and the fact that its acreage is often located in a geographic area of low demand. ${ }^{230}$ But the fundamental causes of the Department's failures inhere in its financial structure. ${ }^{231}$ First, this structure confronts the Department with a clear conflict of interests. Although funding patterns have changed smce 1920, a consistent source of revenue has been the public leasing of Department lands not assigned to Native Hawanan homesteaders. ${ }^{232}$ Today, the Department's internal administrative costs are provided from those receipts. ${ }^{233}$ Although direct legislative appropriation is possible when revenue is insufficient to meet administrative costs, ${ }^{234}$ the Department has usually chosen to generate funds from public leasing, thus withholding valuable property from homesteaders. ${ }^{235}$ Whenever technological improvements or demographic movements make Hawañan home lands valuable, the Department is faced with the choice either of allowing individual Hawaiians to use valuable land or of leasing it to non-Hawaiians in order to fund department expenses. Second, statutory fiscal ceilings stymie assignment of homesites. The Department will not open a houselot tract unless that tract has adequate roads, drainage systems and other improvements. ${ }^{236}$ But the Hawan̈an home-development fund, which finances these non-revenue producing improvements, has a statutory fiscal ceiling. ${ }^{237}$ Similarly, it is Department policy not to award specific homesites unless the land has a completed home or firm construction plans. $^{238}$ Most Native Hawaiians are unable to finance construction

230. See BIenNial ReP. of the Dep't of Hawaitan Home LaNds to the LegislaTURE OF THE STATE OF HAWAII 6 (1971).

231. For a description of the Department's byzantine funding scheme see Program STUDY, supra note 218 , at 54-61.

232. Compare Hawaiian Homes Commission Act of 1920, ch. 42, $\S 213,42$ Stat. 112, with HawaII CoNST., Hawaiian Homes Commission Act, 1920, \& 213 (f).

233. HawarI Const., Hawaiian Homes Commission Act, 1920, \& 213(f). From July 1,1972 to June 30,1973 , the receipts from general leasing totalled $\$ 798,670$, while administrative expenditures were $\$ 558,606$. Statistics supplied in interview with Richard Paglimawin, Deputy Director of the Department of Hawaiian Home Lands, in Honolulu, Hawaii, Nov. 11, 1974.

234. HawaII Const. Hawaiian Homes Commission Act, 1920, § 213(f)(3). If the income produced froin general leases in a fiscal year is greater than the Department's approved budget, the extra revenues spill over into the Hawaiian home-development fund. Id. Thus, in fiscal year $1972-73, \$ 240,064$ from general lease revenue went to that fund.

235. Today over 108,000 acres rae under general lease. LAND INVENTORY, supra note 218, app., table 2. Over 30,000 additional acres of Hawaiian Home Lands in water, forest, aud game conservation districts are not benefiting Native Hawaiians to any greater degree than the public at large. Id.

236. Shapiro, Hawaiian Homes Panel Changes Leasing Policy, Honolulu Star-Bu1letin, May 26, 1973, at A-10, col. 2.

237. The ceiling for the Hawaiian home-development fund is, in fact, $\$ 1,250,000$ because of limitations on its sources of revenue. Program STUdY, supra note 218, at 56.

238. Shapiro, Hawailan Homes Panel Changes Leasing Policy, Honolulu Star-Bulletin, May 26, 1973, at A-10, col. 2. 
of their own homes, ${ }^{239}$ and banks are unwilling to lend money simce Hawaiian Home lands cannot be mortgaged. ${ }^{240}$ New applicants must therefore turn to the Department's Hawaiian home-loan fund for financing $^{241}$ - which also has a fiscal ceiling set by statute. ${ }^{242}$ Thus, when homes cannot be built, land is not assigned to Native Hawaiian homesteaders.

Three major changes could assure more rapid homesteading of the land. First, the Department could assign homesites before houses are constructed, especially within existing tracts that do not need further development. In 1973, the commissioners voted unanimously to release unimproved lands for houselots, ${ }^{243}$ but rescinded their action at the next regular meeting. ${ }^{244}$ Since the Hawaii Attorney General has interpreted the Hawaiian Home lands as being exempt from the zoning powers of the counties, ${ }^{245}$ homesteaders could make immediate use of assigned land, even if they were unable to conform to housing codes. Second, the Department should reverse its present policy of denying houselots to Native Hawaiians whose net assets exceed $\$ 10,000$. Although it might be justifiable for the Department to withhold construction loans from middle-class Native Hawaiians so that its limited funds can provide homes for the poor, the Department has, by favoring general leasing and refusing homesteads to Native Hawanians with sufficient funds to construct their own homes, perpetuated the use of Hawaiian Home lands by non-Hawaïans. Furthermore, it can be argued that Hawaiian Homes communities should reflect the true economic range of the Native Hawaiian community, rather than just its poorest members. Finally, adequate funding is necessary to develop homesteads. The statutory ceilings on the Hawaiian home-loan fund

239. Department regulations forbid the awarding of a houselot to any person with net assets over $\$ 10,000$ or "whose net worth, together with that of his spouse, is in excess of $\$ 15,000 . "$ DEP'T OF HAWAIIAN Home LANDS, RulEs \& REg. $\$ 5.01$ (1973).

240. Hawam Const., Hawaiian Homes Commission Act, 1920, $\$ 208(5)$. As an exception property can be mortgaged to another Native Hawaiian with Department permission. Id.

241. Under the usual arrangennent, the applicaut receives a land lease at a nominal rate, but must make monthly payments to the Department for monies lent for home construction. See discussion in Kila v. Hawailan Homes Commission, No. 74-12 (D. Hawaii, Sept. 17, 1974).

If a honiesteader wishes to surrender a lomestead, the Department must pay him for certain improvements on the property. The Department will then award the homestead to an applicant on the waiting list who must agree to repay the Department that value. HawaII CoNST., Hawaiian Homes Commission Act, 1920, \$ 209(1).

242. The ceiling for the Hawaiian lome-loan fund is $\$ 5,000,000$. HawaIl Const, Hawaiian Hoines Cominission Act, 1920, \$213(b).

243. Howolulu Star-Bulletin, May 26, 1973, at B-1, col. 1.

244. Minutes of Hawaiian Homes Commission, Aug. 31, 1973, on file in Department of Hawaiian Home Lands.

245. Op. HAwAM AtT'Y Gen. 21 (1972). 
and the Hawainan Home-development fund must be removed. The Department should also attempt to generate funds from outside sources, such as the federal government, to finance home construction for Native Hawaiians. ${ }^{246}$ The Department should seek appropriate statutory amendments ${ }^{247}$ to allow use of the Hawaiian home-loan fund to insure the flow of private capital into Hawaiian Homes construction; a small amount of Department funds could thus generate the flow of much greater amounts for capital. A program might be patterned after the federal program of student loans, ${ }^{248}$ with the Department guaranteeing private loans to Native Hawainans. ${ }^{249}$ Such guarantees might encourage banks to grant construction loans without requiring collateral since experience has indicated that most homesteaders will not fall into serious default. ${ }^{250}$

Since the above changes will require a major commitment of funds by the State, the Department must be willing to lead a compaign for the legislative ${ }^{251}$ and budgetary changes necessary to increase utilization of homesteading. It is hardly in position to lead this fight while it is still dependent on general lease revenue for its admimistrative costs. Therefore the State's initial step must be to finance these costs from its general budget. ${ }^{252}$

246. See Program Study, supra note 218 , at 27 for discussion of the difficulties of homesteaders receiving FHA loans. See also, Hawaii H. Con. REs. 56, Reg. Sess. (1971), requesting Hawaii's Congressional delegation to investigate statutory changes to allow Native Hawaiian homesteaders to receive assistance under the National Housing Act of 1949 and from the Farmer's Home Administration.

247. "Both the Admissions Act and the State Constitution delineate the methods by which the HHCA may be amended. [Hawaiian Statehood Act, § 4, 48 U.S.C. Prec. $\S 491$ (1970); Hawaii Const. art. XI, $\$ 3$.] Certain provisions of the Act relating to administration, duties of non-administrative officials, and the increase of benefits to lessees (native Hawaiians) may be amended in the constitution, or in the inanner required for State legislation . . . Generally speaking, all other provisions may be amended only with the consent of the United States." Kila v. Hawaiian Homes Commission, No. 74-12 (D. Hawaii Sept. 17, 1974) (court footnote in brackets). See also LEGAL AsPECTS, supra note 218 , at $66-70$.

248. Higher Education Act of 1965, 20 U.S.C. $\$ 1071-1086$ (1970).

249. Program Study, supra note 218, at 22-25 makes this proposal along with the suggestion for interest subsidies in this era of high interest rates. A bill to allow the Department to make such guarantees was imtroduced into the Hawaii legislature in 1971 but was not passed. H.B. No. 1592 Reg. Sess. (1971).

250. At present, 41 percent of homesteaders are to some degree delinquent on loan payments, but fewer than 20 percent are more than 120 days behind in payments. Honolulu Advertiser, Jan. 30, 1974, at A-13, col. 7.

251. The Department cannot homestead more than 20,000 new acres in any five year period. Hawam Const., Hawaiian Homes Commission Act, 1920, § 204(3). In the past, the Department has never approached this limit, but if homesteading is to be drastically increased, the section may have to be repealed.

252. To guard against any conflict of interest, revenue from the general leasing of Hawaiian Home Lands should not be separately tabulated, but should be included in the State's general revenues. 


\section{Hawaiian Land Claim}

On June 27, 1974, a bill was submitted to the United States House of Representatives "to provide for the settlement of historic claims of the Hawaiian Natives." 253 The bill would establisl an Hawaiian Native Fund of one billion dollars, deposited in 10 equal yearly amounts, to be administered by the Secretary of the Interior. ${ }^{254}$ One corporation would be empowered to make distributions from the Fund to benefit Native Hawainans; ${ }^{255}$ the board of directors would be elected by all fullblood or part-blood Native Hawaiians. ${ }^{256}$ The Hawaiian drive for reparations, spearlieaded by the "ALOHA" movenient (Aboriginal Lands of Hawaiian Ancestry), las grown over the past two years, ${ }^{257}$ partially motivated by the success of the Alaska Native Claims Settlement Act. ${ }^{268}$ Under that settlement, Alaskan Natives will receive almost one billion dollars and 38 million acres of land. ${ }^{250}$ Native Hawaiians see similarities between their claims and those of the Alaskans. In both cases, the United States, without paying compensation to the indigenous population, ${ }^{200}$ gamed title to land in territories that later became states. ${ }^{201}$

The Native Hawaiian land, claim can also be compared to United States conipensation for the lands of Nortl American Indian tribes. Where Indian title to land lrad been recognized, taking could be only by consent, such as a treaty, or by compensation. ${ }^{262}$ Despite the words

253. Hawaiian Native Claims Settlement Act, H.R. 15666, 93d Cong., 2d Sess. (1974). At the time of this writing, the measure had not been introduced in the 94th Congress.

254. Id. $\S 5(\mathrm{a})$.

255. Id. § 6. Compare the Alaska Native Claims Settlement Act, Pub. L. No. $92-$ $203 \S 7$ (a) (Dec. 18, 1971), 85 Stat. 691 in which Congress established 12 regional corporations because of the cultural diversity in Alaska.

256. H.R. 15666, 93d Cong., 2d Sess., \& 6(f) (1974).

257. For an account of Queen Liliuokalani's unsuccessful attempt to seek redress, see Liliuokalani v. United States, 45 Ct. Cl. 418 (1910).

258. Alaska Native Claims Settlement Act, Pub. L. No. 92-203 (Dec. 18, 1971) 85 Stat. 688-716. This bill provided for settlement of a claim filed by Alaskan natives under the Indian Claims Comunission Act, 25 U.S.C. $\$ 70$ (1970). See text accompanying notes $264-70$ infra.

259. Alaska Native Claims Settlenent Act, Pub. L. No. 92-203 (Dec. 18, 1971) §§ 6(a), 12, 85 Stat. 690-91, 701-02.

260. "In both Alaska and Hawaii Organic Acts Congress left open the possibility of a future settlement of land claims." R. Jones, A History of the Alaska Native Claims, April 20, 1973 at 31 (unpublisled study for Congressional Reference Service, in Library of Congress). Compare Alaska Organic Act, ch. 53, 23 Stat. 24, 26 (1884), with Hawaiian Organic Act, ch. 399, \$ 73, 31 Stat. 141 (1900).

261. A nation does not automatically gain title to privately leeld land over which it asserts political sovereignty. See United States v. Percheman, 32 U.S. (7 Pet.) 51, 86 (1833); but cf. Milirrpum v. Nabalco Pty. Ltd., 17 F.L.R. 141, 200 (Austl. 1971). See generally A. SNOW, THE Question of ABORIGINEs (1921).

262. "When the Congress by treaty or other agreement has declared that thereafter Indians were to hold the lands permanently, compensation must be paid for subsequent 
of the fifth amendment, juriśdiction to hear the claims of Indian tribes was removed from the Court of Claims in $1863 .{ }^{263}$ Congress had to pass a special jurisdictional act for each Indian claim, until 1946, when Congress adopted the Indian Claims Commission Act. ${ }^{20}$ The Act vested jurisdiction in the Indian Claims Commission and waived defenses based upon sovereign immunity or the passage of time. ${ }^{205} \mathrm{~A}$ five-year time limit was set for any tribe on the mainland or in Alaska to present specified claims to the Commission:

(1) claims in law or equity arising under the Constitution, laws, treaties, of the United States, and Executive orders of the President; (2) all other claims in law or equity, including those sounding in tort, with respect to which the claimant would have been entitled to sue in a court of the United States if the United States was subject to suit; (3) claims which would result if the treaties, contracts, and agreeinents between the claimant and the United States were revised on the ground of fraud, duress, unconscionable consideration, mututal or unilateral mistake, whether of law or fact, or any other ground cognizable by a court of equity; (4) claims arising from the taking by the United States, whether as the result of a treaty of cession or otherwise, of lands owned or occupied by the clainant without the payment for such lands of conipensation agreed to by the clainiant; and (5) claims based upon fair and honorable dealings, that are not recognized by any existing rule of law or equity ${ }^{260}$

More than 300 claims have been presented under the Act, ${ }^{207}$ many of which were based exclusively on the "fair and honorable dealings" clause. ${ }^{268}$ This clause indicated that moral as well as legal considerations were relevant. ${ }^{209}$ In debate over the bill, then Congressman Henry Jackson stated,

Let us pay out debts to the Indian tribes that sold us the land we live on .... [L]et us make sure that when the Indians have their day in court they have an opportunity to present all their clains of every

taking." Tee-hit-ton Indians v. United States, 348 U.S. 272, 277-378 (1955). But see, D. Brown, Bury MY Heart AT Wounded KNEe (1970) for a contrary view of the treatment of Native Americans by the United States.

263. Act of March 3, 1863, ch. 42, § 9, 12 Stat. 765, 767.

264. 25 U.S.C. $\$ 70(1970)$.

265. Id. $\$ 70$ (a).

266. Id. (enphasis added).

267. See Vance, Indian Claims-The U.S. Experience, 38 SASK. L. REv. 1, 6 (1974).

268. See, e.g., Gila River Pima-Maricopa Indian Community v. United States, 467 F.2d 1351 (Ct. Cl. 1972); Osage Nation of Indians v. United States, 97 F. Supp. 381 (Ct. Cl. 1951).

269. Representative Karl Mundt stated, "If any Indian tribe can prove it has been unfairly and dishonorably dealt with by the United States, it is entitled to recover." 92 CoNG. REC. A4923 (1946) (extension of remarks of Rep. Karl Mundt). 
kind, shape, and variety, so that the problem can be truly solved once and for all . . . .270

Native Hawaiians have not yet received compensation for the less than fair and honorable treatment they suffered at the hands of Western settlers of Hawaii. ${ }^{271}$ Uncompensated taking of title to government and Crown lands by the United States at the time of Annexation could support a compensation claim. There are two interrelated objections to compensating Native Hawaiians. First, some of the lands taken were Crown lands and therefore it can be argued that compensation for them should go to the heirs of Queen Liliuokalani. However, the Court of Claims denied compensation to Queen Liliuokalani partly on the grounds that the land should not be treated as private property. ${ }^{272}$ Second, much of the land taken by the United States after annexation was returned to the State of Hawaii at the time of statehood. ${ }^{273}$ Nevertheiess, the federal government today retains title to approximately 400,000 acres. ${ }^{274}$ Moreover, at the time of statehood Native Hawaiians comprised only a minority of citizenship, unlike their majority status at the time of annexation. ${ }^{275}$ This delay in exchanging federal title for state title cost Native Hawaiians the power to control the use of the returned land. Specific Congressional legislation is probably necessary to authorize a suit for compensation. No action could be brought under the Indian Claims Commission Act which is limited to claims by mainland Indians and Alaskan Natives. ${ }^{276}$ Nor does it seem likely that all action could be brought in the Court of Claims based on its jurisdiction over clains against the United States founded upon the Constitution, ${ }^{277}$ it is doubtful that armexation included a fifth amendment taking ${ }^{278}$ and any claim so founded would probably be timebarred. ${ }^{270}$

270. 92 CONG. REC. 5312 (1946) (remarks of Congressman Jackson).

271. It is doubtful that the Kuleana Act which reduced the land rights of commoners from approximately one-third of the kingdom to fewer than 30,000 acres could support a land claim against the United States. First, the act was passed during the time of the Hawaiuan Kingdom, a half century before American sovereignty was asserted. Additionally the Hawaiian Constitution of 1840 had no clause requiring compensation for the taking of property.

272. Lihuokalani v. United States, 45 Ct. Cl. 418, 527 (1910).

273. See Hawaiian Statehood Act, $\$ 5$, 48 U.S.C. Prec. $\$ 491$ (1970).

274. MAJOR LANDOWNERS, supra note 218 at 99.

275. A. LIND, HAWAII's PEOPLE 27 (1955). Most Chinese and Japanese inhabitants were excluded from citizenship at the time of annexation. See note 115 supra.

276. 25 U.S.C. $\$ 70$ (a) (1970).

277. "The Court of Claims shall have jurisdiction to render judgmeut upon any claim against the United States founded . . . upon the Constitution . . ." 28 U.S.C. \$ 1491 (1970).

278. Cf. Tee-hit-ton Indians v. United States, 348 U.S. 272 (1955).

279. "Every claim of which the Court of Claims has jurisdiction shall be barred un- 
The proposed Hawaiian Native Claims Settlement Act would place a dollar value on the Native Hawaiian land claim, rather than establishing a claims procedure. ${ }^{280}$ Native Hawaiians could thus avoid issues that have complicated other compensation litigation, ${ }^{281}$ for example, the judicial determination of the value of the land at the time of the governmental taking. ${ }^{282}$ In the Alaska Native Claims Settlement Act, Congress determined the total value of the claim in order to avoid such difficulties, ${ }^{283}$ and this procedure should be followed for Hawaii. Since there will be few, if any, additional claims by indigenous people, Congress need not fear the work load inherent in this task of estabhishing the dollar value of land claims.

The Hawaiian Native Claims Settlement Act also avoids a premature decision on whether coinpensation funds should be distributed per capita to the claimants or used for cooperative development. ${ }^{284}$ Funds would be turned over to the Hawaiian Native Corporation, which would be empowered to use funds for either purpose. ${ }^{285}$ By participating in the corporation, Native Hawaiiaus could determine the Fund's uses. ${ }^{280}$ Mary Native Hawainan land problems could be remedied if the corporation allocated funds for community development. For example, funds could be used to defractionate kuleana, to finance housing construction on Hawaiian Home lands, ${ }^{287}$ and to purchase additional lands for Native

less the petition thereon is filed within six years after such claim first accrues." 28 U.S.C. $\$ 2501$ (1970).

280. H.R. 15666, 93d Cong., 2d Sess. § 5(a) (1974).

281. California Indians, for example, began their claims movement in 1902 and did not receive fimal compensation until 1973. For a discussion of the California claims fight see generally $\mathrm{K}$. Johnson, K-344 For THE Indians of CAlIForNIA vs. THe UNITED STATES (1966).

282. Under court-developed doctrines, claimants were not entitled to the land's present value but only to the value of the land at the time of the governmental action, unless that action amounted to a fifth amendment taking, in which case the claimants were also entitled to imputed interest. Compare, e.g., Fort Berthold Reservation v. United States, 390 F.2d 686 (Ct. Cl. 1968) and Uintah and White River and White River Band of Indians, 152 F. Supp. 953 (Ct. Cl. 1957) with United States v. Kiowa, Comanche and Apache Tribes, 163 F. Supp. 603 (Ct. Cl. 1958).

Perhaps the most sensible question conccrning these cases was asked by Professor Monroe Price:

But how much sense does it make for judges, anthropologists, lawyers and Congressmen to go through incredible contortions to determine what occurred one hundred years ago and base compensation on such a determination?

M. PRICE, LAW AND THE AMERICAN INDIAN 356 (1973).

283. See note 259 supra.

284. On the other hand, the Alaska Native Claims Settlement Act, Pub. L. No. 92 203 , § 7(j), 85 Stat. 688 (1971) inandates some per capita distribution.

285. H. 15666, 93d Cong., 2d Sess. \$ 6 (1974).

286. See text accompanying note 256 supra.

287. Interestingly, H.R. 15666 does not vest rights to the Hawaiian Home Lands in the Native Hawaiian Community. 
Hawainans. ${ }^{288}$ If the Bishop Estate needed to sell lands to maintain its liquidity, the corporation could buy them so that the Estate land would continue to serve Native Hawainans.

Compensation to indigenous people is essentially an ethical rather than a legal issue. Annexation removed from Native Hawaiians the opportunity to assert sovereignty over a homeland. The Hawaiian Native Claims Settlement Act would allow Native Hawaiians to reestablish some degree of cultural autonomy.

\section{CONCLUSION}

A central theme of Hawainan history during the past two centuries has been the continual displacement of Native Hawaiians from the control and ownership of the lands of Hawaii. This trend has been less than monolithic; Native Hawainans have received access to a token land base through anneliorative steps suclr as kuleana and the Hawaiian Homes prograin. Recent pressures against Native Hawaiian laud holdings are posed by increased immigration and commercial growth. Just as displacement of Native Hawaiians was accomplished primarily through manipulation of the legal system, so, too, legal action is necessary to assure Native Hawaiians a future on the Islands. Kuleana will continue to be lost unless the legal rights of their owners are protected. Structural clianges are necessary if Native Hawaiians are to fully utilize the Bishop Estate and Hawainan Homes land. One catalyst for change would be a major award from the United States in compensation for lauds taken in the past. But without a concomitant commitment by the legal system to preserve a laud base for Native Hawaiians, their future on the very Islands that nurtured their culture is bleak.

288. The bill would give the corporation first option to acquire return of surplus federal lands. H.R. 15666, 93d Cong., 2d Sess. $\$ 7$ (1974). 